Review

\title{
Cardiac Development: A Glimpse on Its Translational Contributions
}

\author{
Diego Franco *(D), Carlos Garcia-Padilla (D), Jorge N. Dominguez (D), Estefania Lozano-Velasco (D) \\ and Amelia Aranega
}

check for

updates

Citation: Franco, D.; Garcia-Padilla, C.; Dominguez, J.N.; Lozano-Velasco, E.; Aranega, A. Cardiac Development: A Glimpse on Its Translational

Contributions. Hearts 2021, 2, 87-117. https://doi.org/10.3390/

hearts2010008

Received: 21 December 2020

Accepted: 25 January 2021

Published: 4 February 2021

Publisher's Note: MDPI stays neutral with regard to jurisdictional claims in published maps and institutional affiliations.

Copyright: (c) 2021 by the authors. Licensee MDPI, Basel, Switzerland. This article is an open access article distributed under the terms and conditions of the Creative Commons Attribution (CC BY) license (https:// creativecommons.org/licenses/by/ $4.0 /)$.
Department of Experimental Biology B3-362, University of Jaen, 23071 Jaén, Spain; cgp00013@red.ujaen.es (C.G.-P.); jorgendm@ujaen.es (J.N.D.); evelasco@ujaen.es (E.L.-V.); aaranega@ujaen.es (A.A.)

* Correspondence: dfranco@ujaen.es

\begin{abstract}
Cardiac development is a complex developmental process that is initiated soon after gastrulation, as two sets of precardiac mesodermal precursors are symmetrically located and subsequently fused at the embryonic midline forming the cardiac straight tube. Thereafter, the cardiac straight tube invariably bends to the right, configuring the first sign of morphological left-right asymmetry and soon thereafter the atrial and ventricular chambers are formed, expanded and progressively septated. As a consequence of all these morphogenetic processes, the fetal heart acquired a four-chambered structure having distinct inlet and outlet connections and a specialized conduction system capable of directing the electrical impulse within the fully formed heart. Over the last decades, our understanding of the morphogenetic, cellular, and molecular pathways involved in cardiac development has exponentially grown. Multiples aspects of the initial discoveries during heart formation has served as guiding tools to understand the etiology of cardiac congenital anomalies and adult cardiac pathology, as well as to enlighten novels approaches to heal the damaged heart. In this review we provide an overview of the complex cellular and molecular pathways driving heart morphogenesis and how those discoveries have provided new roads into the genetic, clinical and therapeutic management of the diseased hearts.
\end{abstract}

Keywords: cardiac development; transcriptional regulation; congenital heart diseases

\section{Introduction}

Over the last decades, our understanding of the cellular and molecular mechanisms driving cardiac development has greatly increased. Such discoveries have provided clues to dissect the genetic and molecular bases of congenital heart diseases, as well as provided tools to configure novel cellular and molecular approaches to heal the damaged heart. In this review, we provide a comprehensive summary of the cellular and molecular pathways involved in heart formation, and translational contribution of such findings. Therefore, this review will allow clinical cardiologists to discover the contributions of basic cardiovascular development to the clinics and to cardiovascular developmental biologists to envision their therapeutic and clinical potentials.

\subsection{From Gastrulation to the Early Cardiac Linear Tube}

Cardiac development is complex developmental process that is initiated soon after gastrulation. Soon thereafter the epiblast starts delaminating and migrating towards the future mesodermal layer, and cardiac precursors can be traced in the primitive streak (Figure 1A). At this stage, mesoderm precursors are characterized by the expression of Brachyury [1], Mesp1 and Mesp2 [2-4], having all of them an important contribution to early cardiogenic development [5-9]. Following the first configuration of the mesodermal layer, cardiac precursors migrate anteriorly and they start expressing early cardiogenic transcription factors. At this stage, several members of the Forkhead, Nkx, Gata, and 
Mef2 families, respectively, are expressed in the precardiac mesoderm [10-13] in a wide range of different species such as Xenopus [14], zebrafish [15-17], chicken [18-22], and mice [23-30], being particularly important Nkx2.5 [31-34], Gata4 [35-38], and Mef2c [39-43] for early cardiogenesis in different experimental models. Expression of these cardiogenic markers is regulated by signaling factors from the adjacent tissues such as Bmp2 [44-49], Fgf8 [50-53] and Wnt signaling [54-60]. Importantly, Bmp2 and Fgf8 signaling is controlled by an intricated molecular cascade in which non-coding RNAs, such as miR-130 and miR133, are also involved [61]. As development proceed, the initial cardiogenic precursors become configured into a horseshoe shape (Figure 1B) and subsequently the bilateral cardiogenic precursors are fused in the embryonic midline generating a cardiac straight tube [62]. At this stage, the embryonic heart is configured by two distinct epithelial layers, an externally located myocardial layer and an internally located endocardial layer. The two distinct cardiogenic subpopulations can be already recognized at this stage [63,64], the first heart field (FHF) that contributes to the early cardiac straight tube, and the second heart field (SHF) that is medially located and will subsequently contribute to both the arterial and venous poles of the heart [65-67] (Figure 1C). FHF specification is dependent of cardiogenic factors such as Nkx2.5 [68], while SHF specification is mostly determined by islet-1 [69] while Bmp signaling contributes to SHF proliferation [70]. On the other hand, Mef2c is required for both FHF and SHF development [71]. 
A

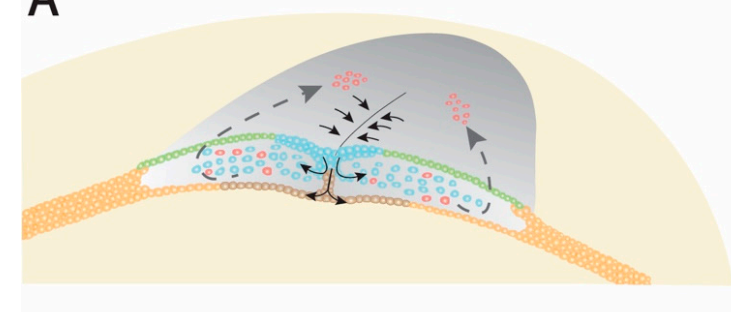

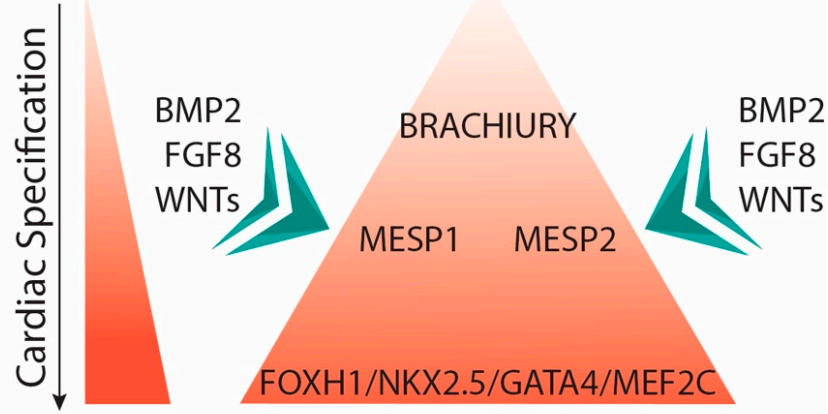

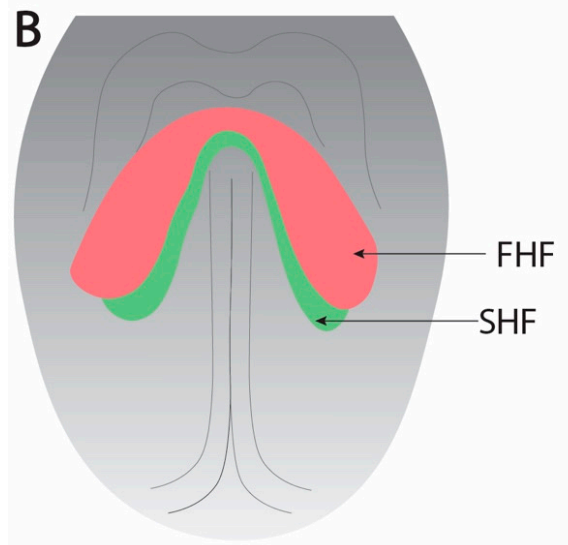

D
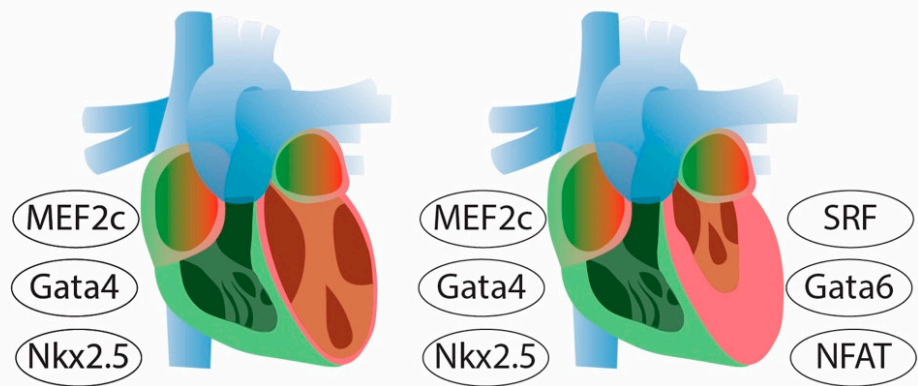

Dilated Cardiomyopathy Hypertrophic Cardiomyopathy

DRUG DISCOVERY ANDTHERAPY

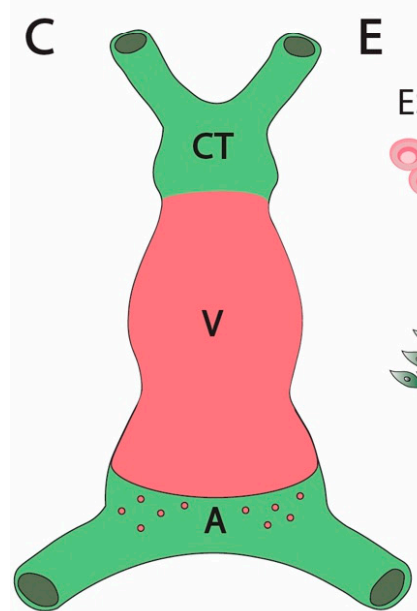

Hanging Drops

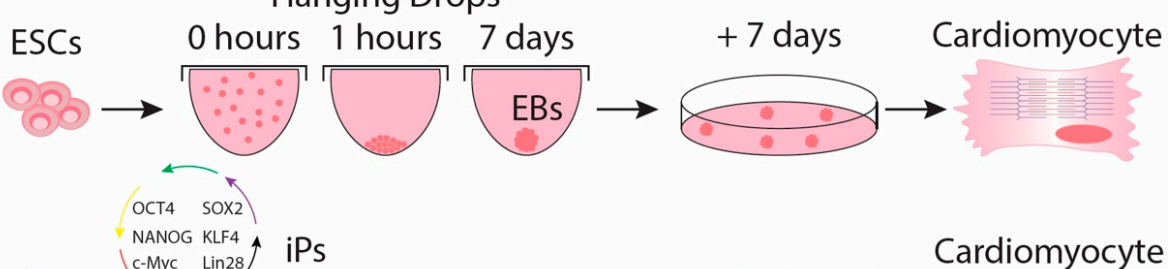

$\left(\begin{array}{cc}\text { C-Myc } & \operatorname{Lin} 28\end{array}\right.$

$e^{\text {Ps }}$
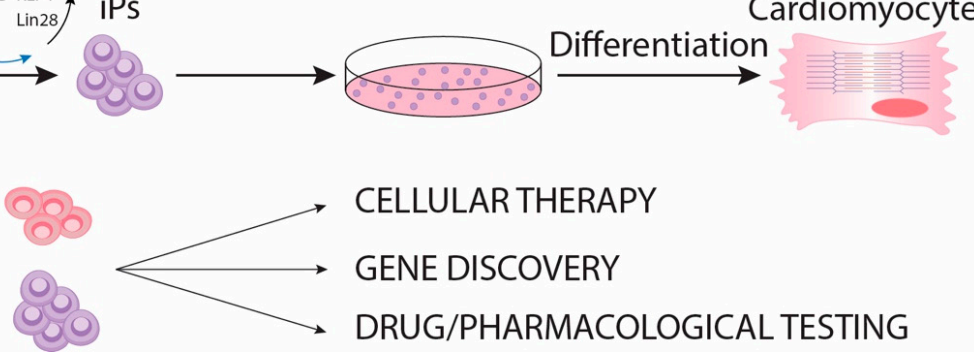

\section{CELLULAR THERAPY}

GENE DISCOVERY

DRUG/PHARMACOLOGICAL TESTING

Figure 1. Early steps of cardiogenesis. Schematic representation of the early steps of cardiac development, initiated at the primitive streak stage with the formation of the cardiogenic precursors (panel A) that soon migrate anteriorly and constitute a horse-shoe cardiac crescent (panel B), and, subsequently, the cardiac straight tube (panel C). Contribution of the FHF and SHF can already be identified at the cardiac crescent stage (panel B). During these morphogenetic events, cardiac specification and determination takes place with the contribution of distinct growth factors and transcription factors, as exemplified in panel A. Impaired expression of these factors is observed in adult cardiac pathologies such as dilated cardiomyopathy or hypertrophic cardiomyopathy (panel D) providing target genes for drug discovery and therapy of these physiopathological conditions [72-77]. Manipulation and implementation of sequential protocols of these growth factors played an important role for directing embryonic stem cells (ESCs) and induced pluripotent stem cells (iPS) cell determination into the cardiomyogenic lineage and thus providing tools for cellular therapy, novel gene discoveries and drug/pharmacological treatments (panel E) [78-93]. 
Genetically modified mice have uncovered key functional roles of distinct transcription factors during early cardiac developmental stages. In this context, Gata4 systemic mutants leads to absence of cardiac tube formation [94,95]. Mef2c and Foxh1 systemic mutants are arrested at the cardiac linear heart tube stage [28,35], while $N k \times 2.5$ mutants failed to develop right after cardiac looping, providing some cues for ventricular left-right development [96]. Importantly, Mef2c, Gata4, and Nkx2.5 constitute coregulators of early cardiac development [97-100]. Moreover, these core cardiac transcription factors can also be associated with additional cofactors during early cardiogenesis such as Tbx5 [101-104], Gata5 [105], and Gata 6 [106], constituting a complex gene regulatory network [107-109] that also implies other transcription factors as reported in different experimental models [110-114].

These transcriptional networks have been studied in detail over the last decades, uncovering a multiple of downstream genes [115-122], including non-coding RNAs, such as miR-99/let-7 [123,124], that are involved in multiple steps of cardiac development as reported in different species. Overall, these data demonstrate that early cardiac development is an intricated morphogenetic mechanisms in which multiple factors are critically involved (Table 1).

Table 1. List of distinct transcription factors involved in cardiogenesis and they main functional contribution to heart development.

\begin{tabular}{|c|c|c|}
\hline TF & Function & References \\
\hline Brachyury & Mesodermal commitment & [1] \\
\hline Mesp1 & Cardiogenic mesoderm commitment & [2-9] \\
\hline Mesp2 & Cardiogenic mesoderm commitment & [2-9] \\
\hline Gata4 & $\begin{array}{c}\text { Early cardiac specification, proepicardium development, chamber } \\
\text { formation, atrial and atrioventricular septation, cardiomyocyte } \\
\text { proliferation, cardiac hypertrophy }\end{array}$ & {$[10-14,27,35-38,94,95,97-100,125-127]$} \\
\hline Gata5 & Early cardiac specification, cardiomyocyte proliferation & {$[10-14,16,26,105]$} \\
\hline Gata6 & Early cardiac specification, cardiac hypertrophy & {$[10-14,16,25,41]$} \\
\hline$N k x 2.3$ & Early cardiac specification & [15] \\
\hline$N k x 2.5$ & $\begin{array}{l}\text { Early cardiac specification, FHF development, cardiac looping, chamber } \\
\text { formation, cardiac conduction system specification, atrial septation }\end{array}$ & {$[15,31-34,68,96-100,128-135]$} \\
\hline$N k x 2.6$ & Early cardiac specification & {$[24,29]$} \\
\hline$N k x 2.7$ & Early cardiac specification & [15] \\
\hline$N k x 2.8$ & Early cardiac specification & [18-20] \\
\hline Foxh1 & Anterior heart field development & {$[28,35]$} \\
\hline $\operatorname{Mef} 2 \mathrm{c}$ & Early cardiac specification, chamber formation & {$[35-43,136]$} \\
\hline Islet-1 & Second heart field specification & [69] \\
\hline $\operatorname{Tbx5}$ & $\begin{array}{l}\text { Early cardiac specification, chamber formation, cardiac conduction } \\
\text { system specification, atrial and ventricular septation }\end{array}$ & {$[101-104,128,137-142]$} \\
\hline Pitx2 & $\begin{array}{c}\text { left right signalling, heterotaxia, chamber formation, cardiac conduction } \\
\text { system development }\end{array}$ & [143-167] \\
\hline $\operatorname{Pr} x 1$ & cardiac looping & [168] \\
\hline Wt1 & proepicardium and epicardial development & {$[169,170]$} \\
\hline $\operatorname{Tcf} 21$ & proepicardium and epicardial development & {$[171,172]$} \\
\hline Tbx18 & proepicardium and epicardial development & [169] \\
\hline$T b x 2$ & primary myocardium and cardiac conduction system development & {$[173-178]$} \\
\hline$T b x 3$ & primary myocardium and cardiac conduction system development & [179-182] \\
\hline$T b \times 20$ & $\begin{array}{c}\text { chamber formation, atrioventricular canal development, cardiomyocyte } \\
\text { cell proliferation }\end{array}$ & {$[183-190]$} \\
\hline $\operatorname{Ir} x 3$ & ventricular trabecular and cardiac conduction system development & {$[191,192]$} \\
\hline $\operatorname{Ir} x 4$ & ventricular chamber development & {$[191,193]$} \\
\hline $\operatorname{Ir} x 5$ & cardiac conduction system development & {$[191,192]$} \\
\hline Hey1 & ventricular chamber development & [194-196] \\
\hline Hey2 & ventricular chamber development & [194-197] \\
\hline Coup-TFII & atrial development & [198] \\
\hline eHand & ventricular development & [199-202] \\
\hline dHand & ventricular development & {$[199,202]$} \\
\hline Foxm1 & ventricular trabecular and compact layers development & [203] \\
\hline Hop & ventricular trabecular and compact layers development & [204] \\
\hline Klf13 & ventricular trabecular and compact layers development & [205] \\
\hline
\end{tabular}


Table 1. Cont.

\begin{tabular}{ccc}
\hline TF & Function & References \\
\hline Brachyury & Mesodermal commitment & {$[1]$} \\
Srf & ventricular trabecular and compact layers development & {$[206,207]$} \\
Shox2 & cardiac conduction development & {$[208-213]$} \\
Odd1 & atrial septation & {$[214]$} \\
Klf2 & atrioventricular septation & {$[215]$} \\
Sox9 & atrioventricular septation & {$[216]$} \\
Smad4 & atrioventricular septation & {$[217]$} \\
Tbx1 & outflow tract and aortic arch development & {$[218]$} \\
Foxc1 & aortic arch development & {$[219]$} \\
Foxc2 & aortic arch development & {$[219]$} \\
Prx1 & aortic arch development & {$[220]$} \\
Prx2 & aortic arch development & {$[220]$} \\
\hline
\end{tabular}

\subsection{Clinical and Translational Perspectives of Early Cardiogenic Development}

Our current understanding of the molecular determinants acting on early cardiogenic differentiation has greatly contributed to provide molecular instruments to convert embryonic stem cells (ESC) into differentiated cardiomyocytes, in both mouse and human ESC, opening thus the possibility to provide novel therapeutic tools to heal the failing heart [79-88] (Figure 1E). Furthermore, several of these key developmental factors have been more recently proposed as developmental clues to differentiate induced pluripotent stem cells into the cardiomyogenic lineage [89-91] even when starting from somatic differentiated fibroblasts $[72,92,93]$, further supporting their plausible application to regenerate the damaged heart.

In addition, the understanding of the early cardiogenetic program have also unraveled the critical role of distinct transcription factors in cardiac adult pathologies [73-75], as well as a fundamental reactivation of these transcription factors in distinct adult cardiac pathological conditions, such as cardiac hypertrophy and dilated cardiomyopathy [75-77] (Figure 1D). Such findings support the notion that cardiac insults primarily respond activating the embryonic genetic program aiming to cope with the dysfunctional capacities caused by such pathologies [221]. 


\subsection{Cardiac Linear Heart and Left-Right Symmetry Break}

Soon after the configuration of the cardiac straight tube, the first morphological left-right asymmetry arises as the heart is detached from the dorsal mesocardium and a rightward bending is invariably observed (Figure 2A). Molecular left-right asymmetry is initiated at earlier developmental stages emanating from the node [222] and transferred to the lateral plate mesoderm by distinct mechanisms including retinoic acid [223,224], Fgf [225-227], Bmp [228-233], Shh signaling [234] and non-coding RNAs [235,236] in a species-specific manner [227-247]. This cascade ultimately converges on Nodal activation in the left lateral plate mesoderm (LPM) [248-251]. Nodal subsequently leads to expression of the homeobox transcription factor Pitx2 in the left LPM [143-146] and thereafter in the emerging mesodermal embryonic structures such as the heart and the gut [147-155] (Table 1). Importantly, impaired expression of Nodal in the left-right lateral plate mesoderm have enormous consequences in early cardiac development, as the looping of the heart can become randomized [156].

Subsequently, expression of Pitx 2 is maintained in the left-sided of the embryonic heart providing thus positional clues to direct left-right cardiac asymmetric morphogenesis [157-165]. Importantly, while overexpressing Pitx2 experiments in the right lateral plate mesoderm are able to drive cardiac leftward looping in Xenopus and chicken embryos [143,144], Pitx2 loss of function in mice does not impairs cardiac looping [145,146], demonstrating that Pitx2 is dispensable for asymmetric cardiac looping. More recently, it has been demonstrated that asymmetric right sided cues directly by Prrx1 are crucial to direct rightward cardiac looping, independent of Pitx2 expression [168] configuring an enhanced epithelial-to-mesenchymal transition (EMT) in the right as compared to the left lateral plate mesoderm, a process that is modulated by distinct microRNAs [252]. 
A
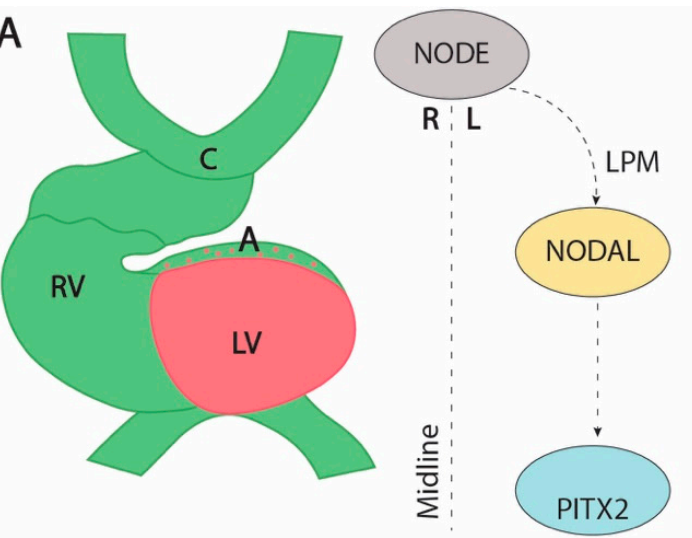

B

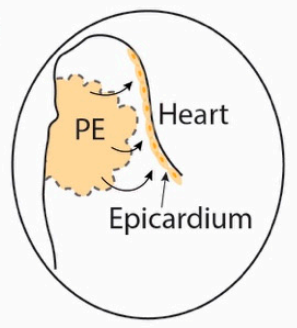

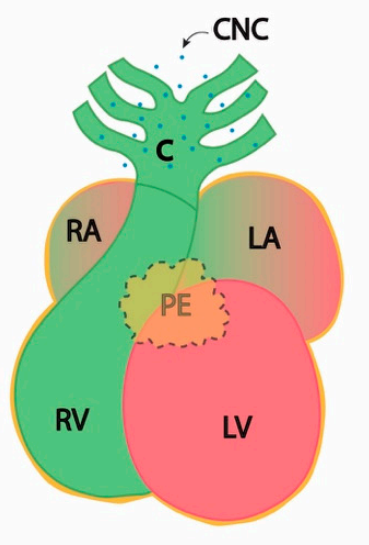

C

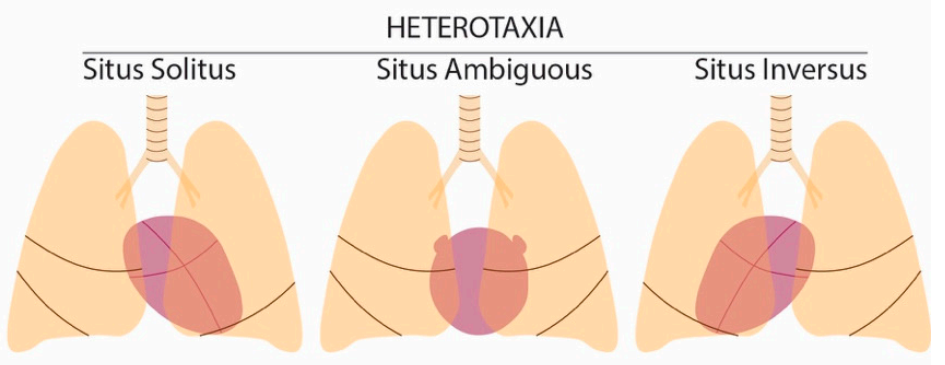

GENETIC SCREENING \& COUNSELING
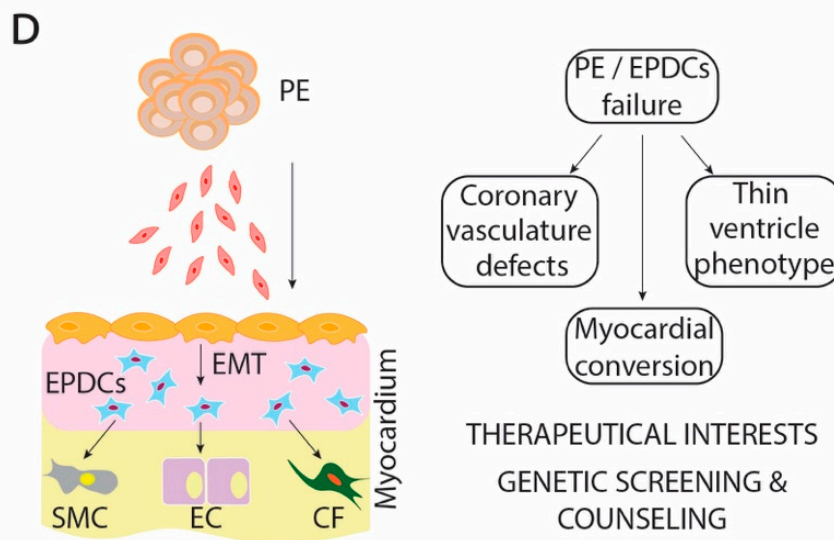

Figure 2. Left-right symmetry break and epicardium development. Schematic representation of the conserved left-right symmetry break molecular cascade, emanating from the node and leading to Nodal and Pitx2 activation in the left lateral plate mesoderm (panel A) [253-261]. As a consequence, cardiac looping takes place (panel A) and the heart display distinct left and right cardiac components that, if impaired, leads to heterotaxia (panel C). Understanding of the molecular cascades directing left-right symmetry break has allowed genetic screening and counseling in these pathophysiological conditions (panel C) [262-274]. In addition, soon after rightward bending of the heart, the proepicardium starts externally covering the naked embryonic myocardium (panel B) and subsequently contributes to distinct cardiac cell types such as vascular endothelial and smooth muscle cells as well as fibroblasts (panel D) [275-299]. Manipulation of the epicardium cell fate can be envisioned as a therapeutic strategy to generate novel cardiomyocytes [300]. Understanding the molecular cascades involved in proepicardium to embryonic epicardium conversion and subsequently to epicardial derived cells (EPCD) will provide soon novel candidate genes for genetic screening and counseling in devastating defects such as left ventricular non compaction and thin ventricular myocardium phenotypes.

\subsection{Clinical and Translational Perspectives of Left-Right Symmetry Break}

The heart is the first organ to display morphological left-right asymmetry during embryogenesis [168]. Abnormal left-right signaling, thus, have a great impact in heart development leading to laterality defects. In humans, three distinct conditions can be observed, situs solitus, in which left-right signaling occurs normally, situs inversus in which left-right signaling is inverted and situs ambiguus in which left-right signaling is randomized. While in situs solitus and situs inversus, cardiac development occurs normally, with no observable morphogenetic defects, in situs ambiguus a large array of morphogenetic defects have been reported, globally termed as heterotaxia syndrome [301-310] (Figure 2C). Namely, isomeric atrial appendages are frequently observed, including abnormal configuration of the venous connections [304-308]. Ventricular chambers are normally not affected while the arterial pole might range from normal connections to double outlet right ventricle (DORV) and in most severely affected cases to permanent truncus arteriosus [304-308]. 
Our understanding of the molecular events leading to impaired left-right signaling has greatly increased over the last years. Primary events leading to symmetry break occurs at the node, as cilia triggered leftwards directional flow is established [253-258], a process that is rather conserved during evolution [259-261]. Impaired cilia function (i.e., primary cilia dyskinesia) underlies cardiac heterotaxia and also several associated syndromes such as Kartagener syndrome [262,263]. Mutations in a wide variety of cilia associated genes have been recently linked to heterotaxia in humans and impaired left-right signaling, including herein ZIC3 [264], dyneins [265-270], LRRC50 [271], CCDC39 [272], and TTC25 [273], among others [274]. In addition to the contribution to heterotaxia of the early left-right symmetry break events, several components of this pathway, such as Nodal, Lefty-1, Lefty-2, and Pitx 2 plays a fundamental role in cardiac isomerism in mice. For example, Lefty-1 knockouts resulted in left isomerism [230], while Pit $x 2$ loss-of-function leads to right atrial isomerism with abnormal venous connections [154,155]. Importantly, impaired Pitx 2 ventricular expression in iv/iv mutants correlated with presence of distinct congenital cardiac defects, such as DORV, supporting the notion that molecular ventricular isomerism is also occurring [159].

\subsection{Externally Covering the Naked Myocardium; the Rise of the Epicardium and Its Derivatives}

Concomitantly with the late stages of cardiac looping the heart is progressive externally covered by a new epithelial layer, the embryonic epicardium. The embryonic epicardium originates from the proepicardium, an epithelial protrusion with a cauli-flower like structure emanating at the junction between the cardiac and the hepatic primordia $[275,276]$ (Figure 2B). The formation of the proepicardium is triggered by distinct factors [277-280], among which it is important to highly the antagonist roles of Bmp [282-285] and Fgf [288-290] family members. After covering the embryonic naked myocardium, the embryonic epicardium is instructed to an epithelial-to-mesenchymal transformation (EMT) leading to the epicardial-derived cells (EPDC) that will subsequently migrate into the embryonic myocardium and will progressively differentiate into distinct cell derivatives such as cardiac fibroblasts as coronary vasculature components such endothelial, smooth muscle cells, and adventitial fibroblasts [291-299] (Figure 2D). The understanding of the molecular events governing proepicardium to embryonic epicardium transition is still in its infancy, yet several cardiac-enriched transcription factors such as Gata4 and Isl1 seems to be playing a critical role $[125,126]$. Similarly, configuration of the proepicardium (PE) is dependent of several transcription factors such as Wt1 [169,170,311], Tcf21 [171,172,242,243], and Tbx18 [312], some of which are also crucial to direct epicardial EMT (Table 1). Importantly, microRNAs such as miR-21 also play a role in this developmental process [313-315]. However, when and how EPDCs acquire their differentiation cues remains yet undetermined although there are some evidence that cell specification might already take place in the PE [316-319], a process that might be dependent of non-coding RNAs [320,321].

\subsection{Clinical and Translational Perspectives of Proepicardium and Epicardium Formation}

Impaired development of the proepicardium and/or failure of the embryonic epicardium to proceed into epithelial to mesenchymal differentiation has profound effects on the development of the embryonic myocardium, leading to a thin ventricular phenotype and absence of proper coronary vessels development [299,322-324]. Such defects are reminiscent of the thin ventricular myocardium phenotype observed in humans, such as left ventricular non-compaction [325-327] although the plausible contribution of the epicardium to this phenotype is still controversial. In addition, impaired epicardial formation also leads to abnormal coronary vasculature development, linking therefore embryonic impairment with adult vascular defects [328]. Therefore, understanding of the cellular and molecular events that takes place during proepicardium to embryonic epicardium transition and their subsequent contribution to the developing cardiac chambers will provide novel candidate genes for genetic screening and counseling in distinct cardiac pathologies 
such as thin ventricular myocardium phenotypes and coronary vasculature impairment (Figure 2D).

\subsection{Cardiac Ballooning and the Configuration Cardiac Conductive System}

Soon after cardiac looping takes place, the prospective atrial and ventricular chambers are progressively formed $[329,330]$. The process by which these prospective chambers is formed is mediated by local increase in proliferation on those areas leading to the working myocardium chambers, whereas lower proliferation is observed on the flanking segments [331] and the embryonic conduction system [332]. In addition to differential cell proliferation, activation of an specific working myocardium gene expression program is initiated, while in the flanking segments such activation is repressed [332,333]. T-box family members such as Tbx2 [173-178], Tbx3 [179-182], Tbx5 [137,138], and Tbx20 [186,187] play a fundamental role instructing these signals [188-190] while atrial and ventricular identities are orchestrated by Irx [191-193], Hey [194-196], and Coup-TF [198] family members. Several non-coding RNAs are differentially expressed during cardiogenesis [334-338], some of which regulate distinct cardiac enriched transcription factors such as Mef2c [334] while other such as miR-25 promotes cardiomyocyte proliferation [336] while others such as miR-143 and miR-138 are essential for cardiac chamber morphogenesis [339,340].

Importantly, both atrial and ventricular chambers are also progressively acquiring left (systemic) and right (venous) identities a process that is directed in first instance by Pitx2 [143,166,341], and subsequently by $e H a n d$ and $d H a n d$ transcription factors [200-202] (Figure 3A). Importantly, transcription factors such as Nkx2.5, Mef2c, and Gata4, that previously provided essential clues during early stages of development, also provide pivotal roles in chamber specific expression during cardiac chamber formation $[127,136]$.

As development proceeds, the atrial and ventricular chamber are progressively maturing. Atrial chambers display minor modifications, with the exception of the development of the pectinated muscles while the ventricular chambers progressively develop a compact myocardial layer while the trabecular network is dynamically restructured. Several key factors have been involved in ventricular trabecular initiation, including herein Notch [342-345] and Neuregulin [346-350] signaling pathways. In addition, several other transcription factors such as Foxm1 [203], Hop [204], Klf13 [205], and Srf [206,207] also play crucial roles at different stages of ventricular trabeculation and compact myocardium maturation (Table 1), resulting in all cases into a thin ventricular phenotype and impaired cardiac function.

Concomitant with these events, the "primitive" myocardium is also re-structured, leading to the formation of the major components of the ventricular conduction system, i.e., the atrioventricular node, the bundle of His, the left and right bundle branches and the peripheral Purkinje fiber network [351-363] (Figure 3B). Several evidence in chicken demonstrate that certain components of the cardiac conduction system were derived from "working" myocardium by endothelin signaling [364-371]. Curiously, such mechanism seems not be involved in mice, where cardiac conduction system and working myocardium display a progressive mechanism of differentiation as revealed by systematic retrospective clonal analyses [372-377]. Furthermore, multiple transcription factors distinctly contribute to the formation of distinct components of the cardiac conduction system such as Nkx2.5 [128-132], Shox2 [208-213], Tbx3 [378], Tbx5 [128], Pitx2 [379], and Wnt signaling [380] (Table 1) and recent evidences also support a role for microRNAs in cardiac conduction system development [381,382].

\subsection{Clinical and Translational Perspectives of Cardiac Ballooning and Conductive Myocardium}

Impairment of the compact myocardium has been observed in multiple mutants [383-389], supporting a causative link with human diseases such as left ventricular non compaction. Similarly, genetic manipulation of several genes [386,387], including transcription factors such as Srf [206,207], Hop [204], Foxm1 [203], and Klf13 [205] led to defects in ventricular compaction, reminiscent of the human left ventricular non-compaction or as in the case of Irx4 [390], to impaired ventricular expression and cardiomyopathy. Therefore, these obser- 
vations have provided candidate genes to dissect the genetic bases of these human cardiac pathological conditions [391-394] (Figure 3C), including also some microRNAs [395-398] and thus providing tools for genetic screening and counseling. In addition, the generating patient specific induced pluripotent stem cells [399] and also opens up new tools for personalized drug testing and reparative medicine.

Instructive signals such as those provided by $T b \times 2$ and $T b \times 3$ configure the precursor backbone of the cardiac conduction system, while the atrial and ventricular chambers are mainly specified by the expression of Hey, Hrt and Irx transcription factors [191-196]. Failure of the proper configuration of the early cardiac conduction system has tremendous effects such as those reported by Aanhaanen et al. [400] and Frank et al. [401] leading the formation of accessory pathways in the adult heart and thus to arrhythmogenic events (Figure 3D).

A
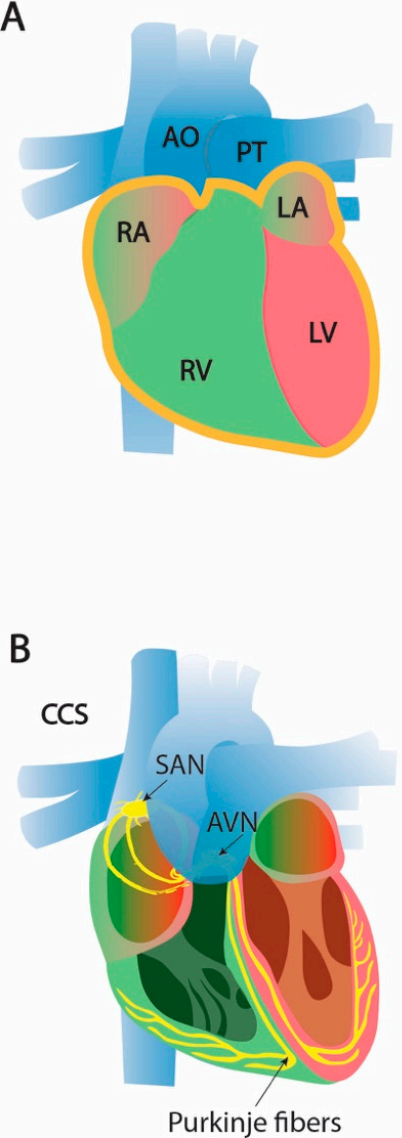

C

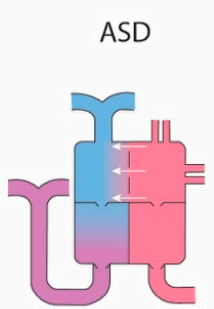

MYH6

NKX2.5

GATA4/6

TBX5/20

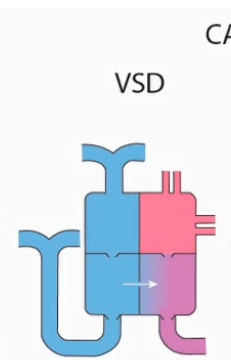

TBX1/5/20

HAND1

GATA4

NKX2.5
CARCIAC SEPTATION

AVSD

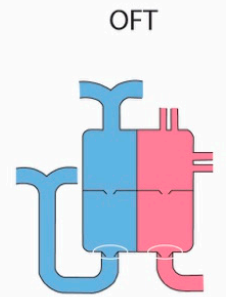

TGA: FOXH1, NKX2.5 DORV: ETS1, HAND2, NKX2.5

GENETIC SCREENING \& COUNSELING

D CARDIAC CONDUCTION SYSTEM

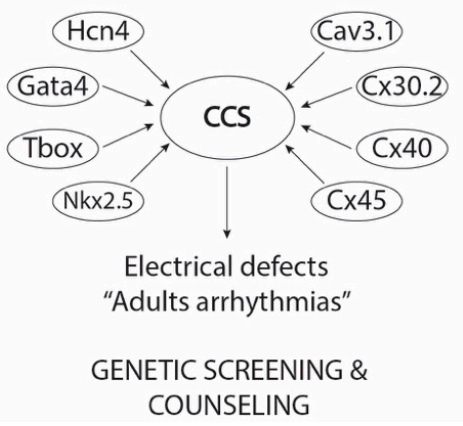

Figure 3. Forming a four-chambered heart. Schematic representation of the fully septated heart (panel A), a process that requires multiple players. Impaired expression and or function of any of them leads to congenital heart diseases (CHD) such as atrial septal defects (ASDs), ventricular septal defects (VSDs), atrioventricular ventricular septal defects (AVSDs), conotruncal abnormalities such as double outlet right ventricle (DORV) or transposition of the great arteries (TGA), aortic arch abnormalities (AAA) or even more complex CHD such as Tetralogy of Fallot (TOF) (panel C). Understanding of the causative genes have provide tools for genetic screening and counseling (panel C) [402-432]. Similarly, our understanding of the cellular and molecular cascades leading to the formation of the cardiac conduction system (CCS) has enormously increased (panel B), providing also tools for genetic screening and counseling of CCS abnormalities (panel D).

\subsection{The Formation of a Four-Chambered Heart: Cardiac Septation}

As development proceeds, septation of the distinct cardiac structures is initiated. At the venous pole, the embryonic atrium is divided into distinct left and right atrial chambers, the atrioventricular canal is remodeled to give rise to the right and left atrioventricular valves, i.e., tricuspid and mitral valve, respectively. At the arterial pole, the embryonic 
ventricle is divided pulmonary (right) and systemic (left) ventricles and the outflow tract into the prospective aortic and pulmonary valves, as detailed below.

\subsubsection{Atrial Septation}

At the venous pole of the heart, atrial chambers are divided through the formation of the primary atrial septum that initially partially separated the right and left atrial chambers. Subsequently, a second atrial septum is formed, providing a two components system of atrial septation that is only fully operative at birth. Primary atrial septation is guided by the cross-talk between the dorsal mesocardial protrusion and the underlying atrial myocardium while second atrial septation seems to be mainly directed by myocardial growth. Atrial septal defects represent the most common cardiac congenital anomaly with an estimate incidence of 1:1000 in newborns. Our understanding of the molecular mechanisms underlying atrial septation have enormously increased over the last decades. Several transcription factors have been reported to play pivotal role in atrial septation, such as Odd1 [214], Nkx2.5 [133-135], Gata4 [433], and Tbx5 [139-142], among others (Table 1). These observations support a critical role of early cardiogenic factors also in atrial septation.

\subsubsection{Atrioventricular Septation}

Concomitant with atrial septation, the separation of the atrioventricular canal is also initiated. Morphogenetically, the atrioventricular canal is initially connecting the future left atrium with the future left ventricle, and thus movements should be generated to provide proper connections with the remaining cardiac chambers, i.e., right ventricle and right atrium [329]. In addition, endocardial cushions of the atrioventricular canal are similarly remodeled, passing from two to four endocardial cushions that subsequently will give rise to the tricuspid and mitral atrioventricular valves, respectively. Our understanding of the molecular and morphogenetic processes leading to endocardial cushion formation and remodeling has greatly enhanced [434]. On the other hand, understanding the mechanisms driven myocardial remodeling of the atrioventricular canal remains more elusive. Importantly, defects in endocardial cushion formation or remodeling results in valvular septal defects, a highly prominent percentage of cardiac congenital anomalies, while impairment of myocardial AVC remodeling might underlie complex morphogenetic defects such as double-inlet left ventricle, which are indeed less frequent. At the molecular level, multiple transcription factors have been reported to play essential roles in atrioventricular septation such as Klf2 [215], Sox9 [216], Gata4 [217,433,435], Smad4 [217], and Mef2 [436], that if impaired, lead to distinct cardiac congenital heart diseases (Table 1).

\subsubsection{Ventricular Septation}

Ventricular septation is initiated with the formation of a muscular interventricular septum that progressively increases in size from the apex to the base of the heart [389]. Complete closure of the interventricular communication is established as the muscular component meets the mesenchymal component at the base of the heart, a structure that is derived from the atrioventricular endocardial cushions [329]. The understanding of the molecular processes that trigger the formation of the muscular interventricular septum are scarce, beyond the fact that both right and left ventricular myocytes contribute to it [437] and that $T b x 5$ and $e H a n d$ play a fundamental role directing the precise position of the interventricular septum (IVS) [201,438] (Table 1). Similarly, our understanding of the molecular mechanisms driving the mesenchymal contribution are also scarce, even most IVS septal defects lack proper development of this mesenchymal component [439,440] and scarce evidence are reported affecting the muscular component [441].

\subsubsection{Outflow Tract Septation and Aortic Arch Remodeling}

Septation of the arterial pole of the heart is initiated with the configuration of the endocardial cushions and the progressive rotation of the outflow tract $[442,443]$. The endocardial cushions are separated into four main and two accessory cushions that progressively 
become separated into the prospective aortic and pulmonary semilunar valves. Septation is triggered by the progressive invasion of the cardiac neural crest cells at the most anterior part of the outflow tract, orchestrating the proper subdivision [444-446]. Failure or impaired migration of the neural crest into the outflow tract results in severe cardiac congenital malformations such as permanent truncus arteriosus (PTA) or in the lesser form of DORV [447-450].

Beside septation of the outflow tract, the final configuration of the arterial outlets is dependent on the proper remodeling of the aortic arches. The paired aortic arches are remodeled in such a way that the IV aortic arch is configured as the aorta and the VI aortic arch into the pulmonary arteries in mice and humans. Failure or improper remodeling of the aortic arches leads to life-threatening defects [451-453]. Cellular and molecular pathways of aortic arch development have been extensive studied, supporting a pivotal role to cardiac neural crest cells [447-450], endothelin [454-456], and retinoic acid [457-459] signaling as well as distinct transcription factors such as Tbx1 [218] and Foxc1/2 [219] and $\operatorname{Prx1/2}$ [220], among others (Table 1) as well as distinct microRNAs [460,461].

\subsection{Clinical and Translational Perspectives of Cardiac Septation}

Understanding the molecular mechanisms that drive impaired cardiac septation has become an entry site for genetic counseling. Over the last decade our understanding of the genetic culprits underlying cardiac septation has enormously increased. Mutations in NKX2.5 and GATA4, have been associated to atrial septal defects [404-409] while mutations HAND2, NKX2.5, and NKX2.6 have been associated to ventricular septal defects [411-413]. Similarly, other genes have been associated to controtuncal defects [414-416], including DORV [417] as well as to complex congenital cardiopathies such as Tetralogy of Fallot $[418,419]$ (Figure 3C). Such information guided to develop genetic strategies for early detection and progressively correction of these congenital heart diseases.

\section{Conclusions}

We have provided in this review an overview of the cellular and molecular mechanisms that contribute to cardiac development, although we aware that it only provides a glimpse of those previously reported mechanisms. We subsequently highlighted the translational applications of the study of heart morphogenesis to distinct aspects of human cardiac diseases, starting from the understanding of the genetic bases of congenital and adult cardiac diseases to the application of these finding in genetic screening and counseling, and finally to the design of therapeutic tools to heal the damaged heart.

\section{Perspectives}

Over the last decades, our understanding of the cellular and molecular processes involved in cardiac morphogenesis has greatly increased. A large number of studied in different species have identified several growth factors and transcription factors with pivotal roles in the cardiogenic lineage commitment. Importantly, several of these factors contribute to multiple facets of cardiac development beyond just the early stages, such as for example chamber formation and valvulogenesis as reported for $N x k 2.5$ and Gata4 ([11-13]), respectively. Furthermore, the functional roles of these early cardiogenic lineage transcription factors are also associated to adult cardiac structural pathologies, such as dilated cardiomyopathy [420-426] or bicuspid aortic valves [427,428] and electrophysiological pathologies such as atrial fibrillation [429-432]. Manipulation of these core transcription factors have provided new tools to convert differentiated cells such as fibroblasts into cardiomyocytes [91], opening new therapeutic opportunities to heal the damaged heart. Importantly, a novel layer of gene regulation is emerging with the identification and functional characterization of non-coding RNAs that are important for cardiomyogenic commitment [462-465], broadening thus the therapeutic tools to provide novel approaches for cardiac repair. 
The embryonic heart is the first organ to display morphological left-right asymmetry. Impairment of sidedness leads to severe body plan abnormalities, including herein cardiac defects. Our knowledge of the molecular and cellular bases of left-right symmetry break has considerably increased over the last decade, providing novel links between early molecular events and impaired sidedness [222]. Such discoveries have served to unravel the genetic bases of heterotaxia and thus as guiding tools for genetic screening and counseling in these human conditions. The discovery of non-coding RNAs involved in early cardiac looping events [252] also exemplify that the final picture of left-right signaling is still incomplete and it would anticipate novel discoveries in the front in the near future.

As cardiac looping takes place, the heart is progressively externally covered by the embryonic epicardium. Importantly, such embryonic epicardium will migrate and deepen into the embryonic myocardium leading to the formation of the cardiac fibroskeleton and part of the coronary vasculature [290-293]. Failure on the formation of the embryonic epicardium or its progenitor cells in the proepicardium is incompatible with life since the ventricular walls are thinner and the coronary vasculature failed to properly form [299]. Curiously, neither the proepicardium or the epicardium leads to significant contribution to the embryonic myocardium in vivo, but if isolated and cultured in vitro, they can do so [290]. Such properties can be used to unlock the cardiomyogenic potential of the epicardium and thus to sever as a source of myocardial differentiation to heal the heart, as previously reported [300,466]. Unlocking these events with non-coding RNAs have been recently reported [321], opening new strategies to heal the damaged heart.

The formation of the cardiac chambers and the cardiac conduction system is an intricated developmental process that is initiated right after left-right symmetry break and thus cardiac looping. Subsequently, the heart displays a complex septation process that provide morphogenetic cues to form a four-chambered organ with distinct inlet and outlet connections. A multitude of different growth factors such as Bmp, Fgf and Wnt family members, and of transcription factors participate on this cardiac developmental orchestra [44-60], and similarly as in the earlier events of heart formation, non-coding RNAs, including herein microRNAs and lncRNAs also participate [61,315,462-464], although our understanding of their functional role is still scarce. Deciphering the molecular cascades involved in these developmental processes have provided candidate genes to test and identify genetic culprits of congenital cardiac anomalies in humans, and thus to design strategies for genetic screening and counseling.

Author Contributions: Conceptualization, D.F.; data curation, D.F.; writing-original draft preparation, D.F.; and E.L.-V.; writing-review and editing, C.G.-P., J.N.D., E.L.-V., A.A. and D.F.; funding acquisition, A.A. and D.F. All authors have read and agreed to the published version of the manuscript.

Funding: This research was funded by Consejeria de Transformación Económica, Industria, Conocimiento y Universidades of the Junta de Andalucia Regional Council, grant number CTS-446.

Institutional Review Board Statement: Not applicable.

Informed Consent Statement: Not applicable.

Data Availability Statement: Not applicable.

Conflicts of Interest: The authors declare no conflict of interest. 


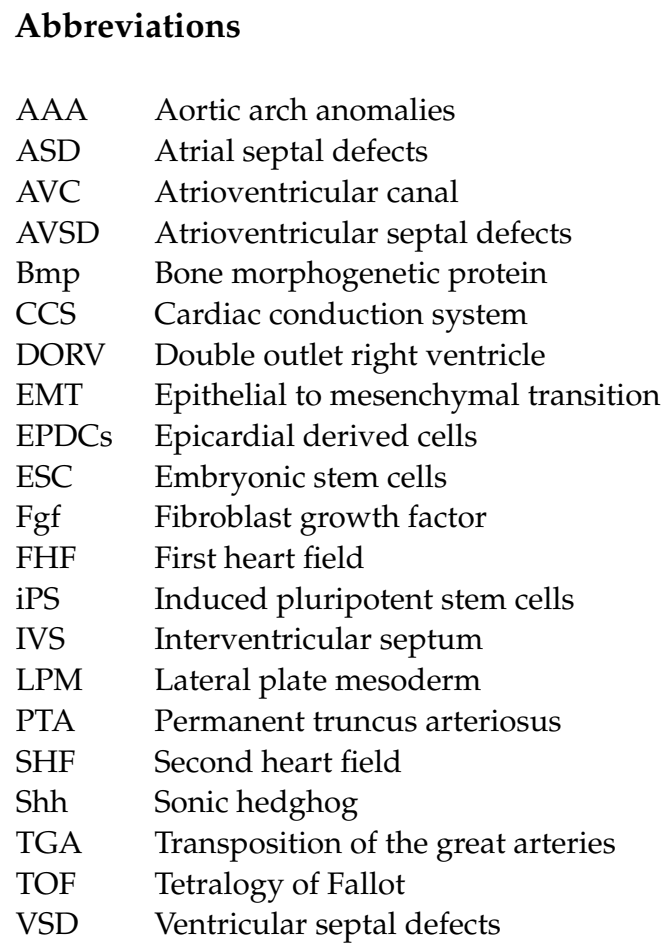

\section{References}

1. Inman, K.E.; Downs, K.M. Localization of Brachyury (T) in embryonic and extraembryonic tissues during mouse gastrulation. Gene Expr. Patterns 2006, 6, 783-793. [CrossRef]

2. Saga, Y.; Miyagawa-Tomita, S.; Takagi, A.; Kitajima, S.; I Miyazaki, J.; Inoue, T. MesP1 is expressed in the heart precursor cells and required for the formation of a single heart tube. Development 1999, 126, 3437-3447.

3. Saga, Y.; Kitajima, S.; Miyagawa-Tomita, S. Mesp1 expression is the earliest sign of cardiovascular development. Trends Cardiovasc. Med. 2000, 10, 345-352. [CrossRef]

4. Kitajima, S.; Takagi, A.; Inoue, T.; Saga, Y. MesP1 and MesP2 are essential for the development of cardiac mesoderm. Development 2000, 127, 3215-3226.

5. Bondue, A.; Lapouge, G.; Paulissen, C.; Semeraro, C.; Iacovino, M.; Kyba, M.; Blanpain, C. Mesp1 Acts as a Master Regulator of Multipotent Cardiovascular Progenitor Specification. Cell Stem Cell 2008, 3, 69-84. [CrossRef]

6. Bondue, A.; Blanpain, C. Mesp1: A key regulator of cardiovascular lineage commitment. Circ. Res. 2010, 107, 1414-1427. [CrossRef]

7. Chan, S.S.-K.; Shi, X.; Toyama, A.; Arpke, R.W.; Dandapat, A.; Iacovino, M.; Kang, J.-J.; Le, G.; Hagen, H.R.; Garry, D.J.; et al. Mesp1 Patterns Mesoderm into Cardiac, Hematopoietic, or Skeletal Myogenic Progenitors in a Context-Dependent Manner. Cell Stem Cell 2013, 12, 587-601. [CrossRef] [PubMed]

8. Lescroart, F.; Chabab, S.; Lin, X.; Rulands, S.; Paulissen, C.; Rodolosse, A.; Auer, H.; Achouri, Y.; Dubois, C.; Bondue, A.; et al. Early lineage restriction in temporally distinct populations of Mesp1 progenitors during mammalian heart development. Nat. Cell Biol. 2014, 16, 829-840. [CrossRef] [PubMed]

9. Chiapparo, G.; Lin, X.; Lescroart, F.; Chabab, S.; Paulissen, C.; Pitisci, L.; Bondue, A.; Blanpain, C. Mesp1 controls the speed, polarity, and directionality of cardiovascular progenitor migration. J. Cell Biol. 2016, 213, 463-477. [CrossRef] [PubMed]

10. Laverriere, A.C.; MacNeill, C.; Mueller, C.; Poelmann, R.E.; Burch, J.B.; Evans, T. GATA-4/5/6, a subfamily of three transcription factors transcribed in developing heart and gut. J. Biol. Chem. 1994, 269, 23177-23184.

11. Charron, F.; Nemer, M. GATA transcription factors and cardiac development. Semin. Cell Dev. Biol. 1999, 10, 85-91. [CrossRef] [PubMed]

12. Burch, J.B. Regulation of GATA gene expression during vertebrate development. Semin. Cell Dev. Biol. 2005, 16, 71-81. [CrossRef] [PubMed]

13. Brewer, A.; Pizzey, J. GATA factors in vertebrate heart development and disease. Expert Rev. Mol. Med. 2006, 8, 1-20. [CrossRef] [PubMed]

14. Jiang, Y.; Evans, T. The Xenopus GATA-4/5/6 genes are associated with cardiac specification and can regulate cardiac-specific transcription during embryogenesis. Dev. Biol. 1996, 174, 258-270. [CrossRef] [PubMed]

15. Lee, K.H.; Xu, Q.; Breitbart, R.E. A new tinman-related gene, nkx2.7, anticipate the expression of nkx2.5 and nkx2.3 in zebrafish heart and pharyngeal endoderm. Dev. Biol. 1996, 180, 722-731. [CrossRef] [PubMed]

16. Holtzinger, A.; Evans, T. Gata5 and Gata6 are functionally redundant in zebrafish for specification of cardiomyocytes. Dev. Biol. 2007, 312, 613-622. [CrossRef] 
17. Sam, J.; Mercer, E.J.; Torregroza, I.; Banks, K.M.; Evans, T. Specificity, redundancy and dosage thresholds among gata4/5/6 genes during zebrafish cardiogenesis. Biol. Open 2020, 9, bio053611. [CrossRef] [PubMed]

18. Reecy, J.; Yamada, M.; Cummings, K.; Sosic, D.; Chen, C.-Y.; Eichele, G.; Olson, E.N.; Schwartz, R.J. Chicken Nkx-2.8: A Novel Homeobox Gene Expressed in Early Heart Progenitor Cells and Pharyngeal Pouch-2 and -3 Endoderm. Dev. Biol. 1997, 188, 295-311. [CrossRef]

19. Boettger, T.; Stein, S.; Kessel, M. The chicken NKX2.8 homeobox gene: A novel member of the NK-2 gene family. Dev. Genes Evol. 1997, 207, 65-70. [CrossRef]

20. Brand, T.; Andrée, B.; Schneider, A.; Buchberger, A.; Arnold, H.-H. Chicken NKx2-8, a novel homeobox gene expressed during early heart and foregut development. Mech. Dev. 1997, 64, 53-59. [CrossRef]

21. Jiang, Y.; Tarzami, S.; Burch, J.B.; Evans, T. Common role for each of the cGATA-4/5/6 genes in the regulation of cardiac morphogenesis. Dev. Genet. 1998, 22, 263-277. [CrossRef]

22. Ban, Q.; Liu, X.; Hui, W.; Chen, D.; Zhao, Z.; Jia, B. Comparative Analysis of Nkx2-5/GATA4/TBX5 Expression in Chicken, Quail and Chicken-quail Hybrids during the Early Stage of Cardiac Development in Embryos. Asian-Australas. J. Anim. Sci. 2013, 26, 476-482. [CrossRef] [PubMed]

23. Heikinheimo, M.; Scandrett, J.M.; Wilson, D.B. Localization of transcription factor GATA-4 to regions of the mouse embryo involved in cardiac development. Dev. Biol. 1994, 164, 361-373. [CrossRef]

24. Harvey, R.P. NK-2Homeobox Genes and Heart Development. Dev. Biol. 1996, 178, 203-216. [CrossRef]

25. Morrisey, E.E.; Ip, H.S.; Lu, M.M.; Parmacek, M.S. GATA-6: A Zinc Finger Transcription Factor That Is Expressed in Multiple Cell Lineages Derived from Lateral Mesoderm. Dev. Biol. 1996, 177, 309-322. [CrossRef] [PubMed]

26. Morrisey, E.E.; Ip, H.S.; Tang, Z.; Lu, M.M.; Parmacek, M.S. GATA-5: A Transcriptional Activator Expressed in a Novel Temporally and Spatially-Restricted Pattern during Embryonic Development. Dev. Biol. 1997, 183, 21-36. [CrossRef]

27. Morrisey, E.E.; Ip, H.S.; Tang, Z.; Parmacek, M.S. GATA-4 activates transcription via two novel domains that are conserved within the GATA-4/5/6 subfamily. J. Biol. Chem. 1997, 272, 8515-8524. [CrossRef]

28. Von Both, I.; Silvestri, C.; Erdemir, T.; Lickert, H.; Walls, J.R.; Henkelman, R.M.; Rossant, J.; Harvey, R.P.; Attisano, L.; Wrana, J.L. Foxh1 is essential for development of the anterior heart field. Dev. Cell 2004, 7, 331-345. [CrossRef] [PubMed]

29. Tanaka, M.; Yamasaki, N.; Izumo, S. Phenotypic Characterization of the Murine Nkx2.6 Homeobox Gene by Gene Targeting. Mol. Cell. Biol. 2000, 20, 2874-2879. [CrossRef]

30. Caprioli, A.; Koyano-Nakagawa, N.; Iacovino, M.; Shi, X.; Ferdous, A.; Harvey, R.P.; Olson, E.N.; Kyba, M.; Garry, D.J. Nkx2-5 Represses Gata1 Gene Expression and Modulates the Cellular Fate of Cardiac Progenitors During Embryogenesis. Circulation 2011, 123, 1633-1641. [CrossRef]

31. Kasahara, H.; Bartunkova, S.; Schinke, M.; Tanaka, M.; Izumo, S. Cardiac and Extracardiac Expression of Csx/Nkx2.5 Homeodomain Protein. Circ. Res. 1998, 82, 936-946. [CrossRef]

32. Tanaka, M.; Chen, Z.; Bartunkova, S.; Yamasaki, N.; Izumo, S. The cardiac homeobox gene Csx/Nkx2.5 lies genetically upstream of multiple genes essential for heart development. Development 1999, 126, 1269-1280. [PubMed]

33. Jamali, M.; Rogerson, P.J.; Wilton, S.; Skerjanc, I.S. Nkx2-5 Activity Is Essential for Cardiomyogenesis. J. Biol. Chem. 2001, 276, 42252-42258. [CrossRef] [PubMed]

34. Harvey, R.P.; Lai, D.; Elliott, D.A.; Biben, C.; Solloway, M.; Prall, O.; Stennard, F.; Schindeler, A.; Groves, N.; Lavulo, L.; et al Homeodomain Factor Nkx2-5 in Heart Development and Disease. Cold Spring Harb. Symp. Quant. Biol. 2002, 67, 107-114. [CrossRef]

35. Lin, Q.; Schwarz, J.; Bucana, C.; Olson, E.N. Control of Mouse Cardiac Morphogenesis and Myogenesis by Transcription Factor MEF2C. Science 1997, 276, 1404-1407. [CrossRef] [PubMed]

36. Bi, W.; Drake, C.J.; Schwarz, J.J. The Transcription Factor MEF2C-Null Mouse Exhibits Complex Vascular Malformations and Reduced Cardiac Expression of Angiopoietin 1 and VEGF. Dev. Biol. 1999, 211, 255-267. [CrossRef]

37. Karamboulas, C.; Dakubo, G.D.; Liu, J.; De Repentigny, Y.; Yutzey, K.; Wallace, V.A.; Kothary, R.; Skerjanc, I.S. Disruption of MEF2 activity in cardiomyoblasts inhibits cardiomyogenesis. J. Cell. Sci. 2006, 119 Pt 20, 4315-4321. [CrossRef]

38. Materna, S.C.; Sinha, T.; Barnes, R.M.; Van Bueren, K.L.; Black, B.L. Cardiovascular development and survival require Mef2c function in the myocardial but not the endothelial lineage. Dev. Biol. 2019, 445, 170-177. [CrossRef]

39. Gajewski, K.; Fossett, N.; Molkentin, J.D.; A Schulz, R. The zinc finger proteins Pannier and GATA4 function as cardiogenic factors in Drosophila. Development 1999, 126, 5679-5688.

40. Pu, W.T.; Ishiwata, T.; Juraszek, A.L.; Ma, Q.; Izumo, S. GATA4 is a dosage-sensitive regulator of cardiac morphogenesis. Dev. Biol. 2004, 275, 235-244. [CrossRef]

41. Zhao, R.; Watt, A.J.; Battle, M.A.; Li, J.; Bondow, B.J.; Duncan, S.A. Loss of both GATA4 and GATA6 blocks cardiac myocyte differentiation and results in acardia in mice. Dev. Biol. 2008, 317, 614-619. [CrossRef] [PubMed]

42. Haworth, K.E.; Kotecha, S.; Mohun, T.J.; Latinkić, B.V. GATA4 and GATA5 are essential for heart and liver development in Xenopus embryos. BMC Dev. Biol. 2008, 8, 74. [CrossRef]

43. Martin, J.; Afouda, B.A.; Hoppler, S. Wnt/beta-catenin signalling regulates cardiomyogenesis via GATA transcription factors. J. Anat. 2010, 216, 92-107. [CrossRef]

44. Clement, J.H.; Fettes, P.; Knöchel, S.; Lef, J.; Knöchel, W. Bone morphogenetic protein 2 in the early development of Xenopus laevis. Mech. Dev. 1995, 52, 357-370. [CrossRef] 
45. Ladd, A.N.; Yatskievych, T.A.; Antin, P.B. Regulation of avian cardiac myogenesis by activin/TGFbeta and bone morphogenetic proteins. Dev. Biol. 1998, 204, 407-419. [CrossRef] [PubMed]

46. Monzen, K.; Shiojima, I.; Hiroi, Y.; Kudoh, S.; Oka, T.; Takimoto, E.; Hayashi, D.; Hosoda, T.; Habara-Ohkubo, A.; Nakaoka, T.; et al. Bone Morphogenetic Proteins Induce Cardiomyocyte Differentiation through the Mitogen-Activated Protein Kinase Kinase Kinase TAK1 and Cardiac Transcription Factors Csx/Nkx-2.5 and GATA-4. Mol. Cell. Biol. 1999, 19, 7096-7105. [CrossRef]

47. Schlange, T.; Andrée, B.; Arnold, H.-H.; Brand, T. BMP2 is required for early heart development during a distinct time period. Mech. Dev. 2000, 91, 259-270. [CrossRef]

48. Christiaen, L.A.; Stolfi, A.; Levine, M. BMP signaling coordinates gene expression and cell migration during precardiac mesoderm development. Dev. Biol. 2010, 340, 179-187. [CrossRef] [PubMed]

49. Gavrilov, S.; Lacy, E. Genetic dissection of ventral folding morphogenesis in mouse: Embryonic visceral endoderm-supplied BMP2 positions head and heart. Curr. Opin. Genet. Dev. 2013, 23, 461-469. [CrossRef]

50. Reifers, F.; Walsh, E.C.; Léger, S.; Stainier, D.Y.; Brand, M. Induction and differentiation of the zebrafish heart requires fibroblast growth factor 8 (fgf8/acerebellar). Development 2000, 127, 225-235.

51. Lopez-Sanchez, C.; Climent, V.; Schoenwolf, G.C.; Alvarez, I.S.; Garcia-Martinez, V. Induction of cardiogenesis by Hensen's node and fibroblast growth factors. Cell Tissue Res. 2002, 309, 237-249. [CrossRef]

52. Alsan, B.H.; Schultheiss, T.M. Regulation of avian cardiogenesis by Fgf8 signaling. Development 2002, 129, $1935-1943$.

53. Ilagan, R.; Abu-Issa, R.; Brown, D.; Yang, Y.-P.; Jiao, K.; Schwartz, R.J.; Klingensmith, J.; Meyers, E.N. Fgf8 is required for anterior heart field development. Development 2006, 133, 2435-2445. [CrossRef]

54. Marvin, M.J.; Di Rocco, G.; Gardiner, A.; Bush, S.M.; Lassar, A.B. Inhibition of Wnt activity induces heart formation from posterior mesoderm. Genes Dev. 2001, 15, 316-327. [CrossRef]

55. Nakamura, T.; Sano, M.; Songyang, Z.; Schneider, M.D. A Wnt-and beta-catenin-dependent pathway for mammalian cardiac myogenesis. Proc. Natl. Acad. Sci. USA 2003, 100, 5834-5839. [CrossRef]

56. Eisenberg, L.M.; Eisenberg, C.A. Evaluating the role of Wnt signal transduction in promoting the development of the heart. Sci. World J. 2007, 7, 161-176. [CrossRef] [PubMed]

57. Foley, A.C.; Mercola, M. Heart induction by Wnt antagonists depends on the homeodomain transcription factor Hex. Genes Dev. 2005, 19, 387-396. [CrossRef]

58. Klaus, A.; Saga, Y.; Taketo, M.M.; Tzahor, E.; Birchmeier, W. Distinct roles of Wnt/beta-catenin and Bmp signaling during early cardiogenesis. Proc. Natl. Acad. Sci. USA 2007, 104, 18531-18536. [CrossRef] [PubMed]

59. Liu, Z.; Li, T.; Liu, Y.; Jia, Z.; Li, Y.; Zhang, C.; Chen, P.; Ma, K.; Affara, N.; Zhou, C. WNT signaling promotes Nkx2.5 expression and early cardiomyogenesis via downregulation of Hdac1. Biochim. Biophys. Acta (BBA)-Bioenerg. 2009, 1793, 300-311. [CrossRef] [PubMed]

60. Jain, R.; Li, D.; Gupta, M.; Manderfield, L.J.; Ifkovits, J.L.; Wang, Q.; Liu, F.; Liu, Y.; Poleshko, A.; Padmanabhan, A.; et al. Integration of Bmp and Wnt signaling by Hopx specifies commitment of cardiomyoblasts. Science 2015, 348, aaa6071. [CrossRef]

61. Lopez-Sanchez, C.; Franco, D.; Bonet, F.; Garcia-Lopez, V.; Aranega, A.; Garcia-Martinez, V. Negative Fgf8-Bmp2 feed-back is regulated by miR-130 during early cardiac specification. Dev. Biol. 2015, 406, 63-73. [CrossRef]

62. Christoffels, V.M.; Habets, P.E.; Franco, D.; Campione, M.; de Jong, F.; Lamers, W.H.; Bao, Z.Z.; Palmer, S.; Biben, C.; Harvey, R.P.; et al. Chamber formation and morphogenesis in the developing mammalian heart. Dev. Biol. 2000, 223, 266-278. [CrossRef] [PubMed]

63. Meilhac, S.M.; Kelly, R.G.; Rocancourt, D.; Eloy-Trinquet, S.; Nicolas, J.-F.; Buckingham, M.E. A retrospective clonal analysis of the myocardium reveals two phases of clonal growth in the developing mouse heart. Development 2003, 130, 3877-3889. [CrossRef] [PubMed]

64. Meilhac, S.M.; Esner, M.; Kelly, R.G.; Nicolas, J.-F.; Buckingham, M.E. The Clonal Origin of Myocardial Cells in Different Regions of the Embryonic Mouse Heart. Dev. Cell 2004, 6, 685-698. [CrossRef]

65. Buckingham, M.E.; Meilhac, S.M.; Zaffran, S. Building the mammalian heart from two sources of myocardial cells. Nat. Rev. Genet. 2005, 6, 826-835. [CrossRef]

66. Meilhac, S.M.; Lescroart, F.; Blanpain, C.; Buckingham, M.E. Cardiac cell lineages that form the heart. Cold Spring Harb. Perspect. Med. 2014, 4, a013888. [CrossRef]

67. Meilhac, S.M.; Buckingham, M. The deployment of cell lineages that form the mammalian heart. Nat. Rev. Cardiol. 2018, 15, 705-724. [CrossRef]

68. Zhang, L.; Nomura-Kitabayashi, A.; Sultana, N.; Cai, W.; Cai, X.; Moon, A.M.; Cai, C.-L. Mesodermal Nkx2.5 is necessary and sufficient for early second heart field development. Dev. Biol. 2014, 390, 68-79. [CrossRef]

69. Cai, C.-L.; Liang, X.; Shi, Y.; Chu, P.-H.; Pfaff, S.L.; Chen, J.; Evans, S.M. Isl1 Identifies a Cardiac Progenitor Population that Proliferates Prior to Differentiation and Contributes a Majority of Cells to the Heart. Dev. Cell 2003, 5, 877-889. [CrossRef]

70. Dyer, L.A.; Makadia, F.A.; Scott, A.; Pegram, K.; Hutson, M.R.; Kirby, M.L. BMP signaling modulates hedgehog-induced secondary heart field proliferation. Dev. Biol. 2010, 348, 167-176. [CrossRef]

71. Hinits, Y.; Pan, L.; Walker, C.; Dowd, J.; Moens, C.B.; Hughes, S.M. Zebrafish Mef2ca and Mef2cb are essential for both first and second heart field cardiomyocyte differentiation. Dev. Biol. 2012, 369, 199-210. [CrossRef] 
72. Van Oort, R.J.; van Rooij, E.; Bourajjaj, M.; Schimmel, J.; Jansen, M.A.; van der Nagel, R.; Doevendans, P.A.; Schneider, M.D.; van Echteld, C.J.; De Windt, L.J. MEF2 activates a genetic program promoting chamber dilation and contractile dysfunction in calcineurin-induced heart failure. Circulation 2006, 114, 298-308. [CrossRef]

73. Oka, T.; Maillet, M.; Watt, A.J.; Schwartz, R.J.; Aronow, B.J.; Duncan, S.A.; Molkentin, J.D. Cardiac-Specific Deletion of Gata4 Reveals Its Requirement for Hypertrophy, Compensation, and Myocyte Viability. Circ. Res. 2006, 98, 837-845. [CrossRef] [PubMed]

74. Muñoz, J.P.; Collao, A.; Chiong, M.; Maldonado, C.; Adasme, T.; Carrasco, L.; Ocaranza, P.; Bravo-Sagua, R.; González, L.; Díaz-Araya, G.; et al. The transcription factor MEF2C mediates cardiomyocyte hypertrophy induced by IGF-1 signaling. Biochem. Biophys. Res. Commun. 2009, 388, 155-160. [CrossRef]

75. Liang, Q.; De Windt, L.J.; Witt, S.A.; Kimball, T.R.; Markham, B.E.; Molkentin, J.D. The Transcription Factors GATA4 and GATA6 Regulate Cardiomyocyte Hypertrophy in Vitro and in Vivo. J. Biol. Chem. 2001, 276, 30245-30253. [CrossRef] [PubMed]

76. Kontaraki, J.E.; Parthenakis, F.I.; Patrianakos, A.; Karalis, I.K.; Vardas, P.E. Altered expression of early cardiac marker genes in circulating cells of patients with hypertrophic cardiomyopathy. Cardiovasc. Pathol. 2007, 16, 329-335. [CrossRef]

77. Van Berlo, J.H.; Elrod, J.W.; van den Hoogenhof, M.M.; York, A.J.; Aronow, B.J.; Duncan, S.A.; Molkentin, J.D. The transcription factor GATA-6 regulates pathological cardiac hypertrophy. Circ Res. 2010, 107, 1032-1040. [CrossRef] [PubMed]

78. Coppola, A.; Romito, A.; Borel, C.; Gehrig, C.; Gagnebin, M.; Falconnet, E.; Izzo, A.; Altucci, L.; Banfi, S.; Antonarakis, S.E.; et al. Cardiomyogenesis is controlled by the miR-99a/let-7c cluster and epigenetic modifications. Stem Cell Res. 2014, 12, 323-337. [CrossRef]

79. Ménard, C.; Grey, C.; Méry, A.; Zeineddine, D.; Aimond, F.; Pucéat, M. Cardiac specification of embryonic stem cells. J. Cell. Biochem. 2004, 93, 681-687. [CrossRef]

80. Glass, C.; Singla, R.; Arora, A.; Singla, D.K. Mouse Embryonic Stem Cell-Derived Cardiac Myocytes in a Cell Culture Dish. Methods Mol. Biol. 2015, 1299, 145-152. [CrossRef] [PubMed]

81. Kawai, T.; Takahashi, T.; Esaki, M.; Ushikoshi, H.; Nagano, S.; Fujiwara, H.; Kosai, K. Efficient cardiomyogenic differentiation of embryonic stem cell by fibroblast growth factor 2 and bone morphogenetic protein 2. Circ. J. 2004, 68, 691-702. [CrossRef] [PubMed]

82. Zimmermann, W.-H. Embryonic and embryonic-like stem cells in heart muscle engineering. J. Mol. Cell. Cardiol. 2011, 50, 320-326. [CrossRef]

83. Kinney, M.A.; Sargent, C.Y.; McDevitt, T.C. Temporal Modulation of $\beta$-Catenin Signaling by Multicellular Aggregation Kinetics Impacts Embryonic Stem Cell Cardiomyogenesis. Stem Cells Dev. 2013, 22, 2665-2677. [CrossRef]

84. Maltsev, V.A.; Rohwedel, J.; Hescheler, J.; Wobus, A.M. Embryonic stem cells differentiate in vitro into cardiomyocytes representing sinusnodal, atrial and ventricular cell types. Mech. Dev. 1993, 44, 41-50. [CrossRef]

85. Paige, S.L.; Plonowska, K.; Xu, A.; Wu, S.M. Molecular regulation of cardiomyocyte differentiation. Circ. Res. 2015, 116, 341-353. [CrossRef] [PubMed]

86. Sluijter, J.P.; Van Mil, A.; Van Vliet, P.; Metz, C.H.; Liu, J.; Doevendans, P.A.; Goumans, M.-J. MicroRNA-1 and -499 Regulate Differentiation and Proliferation in Human-Derived Cardiomyocyte Progenitor Cells. Arter. Thromb. Vasc. Biol. 2010, 30, 859-868. [CrossRef] [PubMed]

87. Turbendian, H.K.; Gordillo, M.; Tsai, S.-Y.; Lu, J.; Kang, G.; Liu, T.-C.; Tang, A.; Liu, S.; Fishman, G.I.; Evans, T. GATA factors efficiently direct cardiac fate from embryonic stem cells. Development 2013, 140, 1639-1644. [CrossRef]

88. Zhang, Z.; Zhang, A.D.; Kim, L.J.; Nam, Y.-J. Ensuring expression of four core cardiogenic transcription factors enhances cardiac reprogramming. Sci. Rep. 2019, 9, 1-10. [CrossRef]

89. Schweizer, P.A.; Darche, F.F.; Ullrich, N.D.; Geschwill, P.; Greber, B.; Rivinius, R.; Seyler, C.; Müller-Decker, K.; Draguhn, A.; Utikal, J.; et al. Subtype-specific differentiation of cardiac pacemaker cell clusters from human induced pluripotent stem cells. Stem Cell Res. Ther. 2017, 8, 1-15. [CrossRef] [PubMed]

90. Kempf, H.; Zweigerdt, R. Scalable Cardiac Differentiation of Pluripotent Stem Cells Using Specific Growth Factors and Small Molecules. Adv. Biochem. Eng. Biotechnol. 2017, 163, 39-69. [CrossRef]

91. Hartung, S.; Schwanke, K.; Haase, A.; David, R.; Franz, W.-M.; Martin, U.; Zweigerdt, R. Directing Cardiomyogenic Differentiation of Human Pluripotent Stem Cells by Plasmid-Based Transient Overexpression of Cardiac Transcription Factors. Stem Cells Dev. 2013, 22, 1112-1125. [CrossRef]

92. Ieda, M.; Fu, J.-D.; Delgado-Olguin, P.; Vedantham, V.; Hayashi, Y.; Bruneau, B.G.; Srivastava, D. Direct Reprogramming of Fibroblasts into Functional Cardiomyocytes by Defined Factors. Cell 2010, 142, 375-386. [CrossRef]

93. Zhang, Z.; Li, H.; Ma, Z.; Feng, J.; Gao, P.; Dong, H.; Zhang, Z. Efficient cardiomyogenic differentiation of bone marrow mesenchymal stromal cells by combination of Wnt11 and bone morphogenetic protein 2. Exp. Biol. Med. 2012, 237, 768-776. [CrossRef]

94. Kuo, C.T.; E Morrisey, E.; Anandappa, R.; Sigrist, K.; Lu, M.M.; Parmacek, M.S.; Soudais, C.; Leiden, J.M. GATA4 transcription factor is required for ventral morphogenesis and heart tube formation. Genes Dev. 1997, 11, 1048-1060. [CrossRef]

95. Molkentin, J.D.; Lin, Q.; Duncan, S.A.; Olson, E.N. Requirement of the transcription factor GATA4 for heart tube formation and ventral morphogenesis. Genes Dev. 1997, 11, 1061-1072. [CrossRef]

96. Biben, C.; Harvey, R.P. Homeodomain factor Nkx2-5 controls left/right asymmetric expression of bHLH gene eHand during murine heart development. Genes Dev. 1997, 11, 1357-1369. [CrossRef] [PubMed] 
97. Durocher, D.; Charron, F.; Warren, R.; Schwartz, R.J.; Nemer, M. The cardiac transcription factors Nkx2-5 and GATA-4 are mutual cofactors. EMBO J. 1997, 16, 5687-5696. [CrossRef]

98. Skerjanc, I.S.; Petropoulos, H.; Ridgeway, A.G.; Wilton, S. Myocyte enhancer factor 2C and Nkx2-5 up-regulate each other's expression and initiate cardiomyogenesis in P19 cells. J. Biol. Chem. 1998, 273, 34904-34910. [CrossRef] [PubMed]

99. Shiojima, I.; Komuro, I.; Oka, T.; Hiroi, Y.; Mizuno, T.; Takimoto, E.; Monzen, K.; Aikawa, R.; Akazawa, H.; Yamazaki, T.; et al. Context-dependent Transcriptional Cooperation Mediated by Cardiac Transcription Factors Csx/Nkx-2.5 and GATA-4. J. Biol. Chem. 1999, 274, 8231-8239. [CrossRef] [PubMed]

100. Vincentz, J.W.; Barnes, R.M.; Firulli, B.A.; Conway, S.J.; Firulli, A.B. Cooperative interaction of Nkx2.5 and Mef2c transcription factors during heart development. Dev. Dyn. 2008, 237, 3809-3819. [CrossRef] [PubMed]

101. Ghosh, T.K.; Song, F.F.; Packham, E.A.; Buxton, S.; Robinson, T.E.; Ronksley, J.; Self, T.; Bonser, A.J.; Brook, J.D. Physical Interaction between TBX5 and MEF2C Is Required for Early Heart Development. Mol. Cell. Biol. 2009, 29, 2205-2218. [CrossRef]

102. Hiroi, Y.; Kudoh, S.; Monzen, K.; Ikeda, Y.; Yazaki, Y.; Nagai, R.; Komuro, I. Tbx5 associates with Nkx2-5 and synergistically promotes cardiomyocyte differentiation. Nat. Genet. 2001, 28, 276-280. [CrossRef] [PubMed]

103. Maitra, M.; Schluterman, M.K.; Nichols, H.A.; Richardson, J.A.; Lo, C.W.; Srivastava, D.; Garg, V. Interaction of Gata4 and Gata6 with Tbx5 is critical for normal cardiac development. Dev. Biol. 2009, 326, 368-377. [CrossRef] [PubMed]

104. Pradhan, L.; Gopal, S.; Li, S.; Ashur, S.; Suryanarayanan, S.; Kasahara, H.; Nam, H.-J. Intermolecular Interactions of Cardiac Transcription Factors NKX2.5 and TBX5. Biochemistry 2016, 55, 1702-1710. [CrossRef] [PubMed]

105. Singh, M.K.; Li, Y.; Li, S.; Cobb, R.M.; Zhou, D.; Lu, M.M.; Epstein, J.A.; Morrisey, E.E.; Gruber, P.J. Gata4 and Gata5 Cooperatively Regulate Cardiac Myocyte Proliferation in Mice. J. Biol. Chem. 2010, 285, 1765-1772. [CrossRef]

106. Charron, F.; Paradis, P.; Bronchain, O.; Nemer, G.; Nemer, M. Cooperative Interaction between GATA-4 and GATA-6 Regulates Myocardial Gene Expression. Mol. Cell. Biol. 1999, 19, 4355-4365. [CrossRef] [PubMed]

107. Prall, O.W.; Menon, M.K.; Solloway, M.J.; Watanabe, Y.; Zaffran, S.; Bajolle, F.; Biben, C.; McBride, J.J.; Robertson, B.R.; Chaulet, H.; et al. An Nkx2-5/Bmp2/Smad1 negative feedback loop controls heart progenitor specification and proliferation. Cell 2007, 128, 947-959. [CrossRef]

108. Schlesinger, J.; Schueler, M.; Grunert, M.; Fischer, J.J.; Zhang, Q.; Krueger, T.; Lange, M.; Tönjes, M.; Dunkel, I.; Sperling, S. The Cardiac Transcription Network Modulated by Gata4, Mef2a, Nkx2.5, Srf, Histone Modifications, and MicroRNAs. PLoS Genet. 2011, 7, e1001313. [CrossRef] [PubMed]

109. Zhou, L.; Liu, Y.; Lu, L.; Lu, X.; Dixon, R.A. Cardiac Gene Activation Analysis in Mammalian Non-Myoblasic Cells by Nkx2-5, Tbx5, Gata4 and Myocd. PLoS ONE 2012, 7, e48028. [CrossRef] [PubMed]

110. Lu, J.R.; McKinsey, T.A.; Xu, H.; Wang, D.Z.; Richardson, J.A.; Olson, E.N. FOG-2, a heart- and brain-enriched cofactor for GATA transcription factors. Mol. Cell. Biol. 1999, 19, 4495-4502. [CrossRef]

111. Akazawa, H.; Kudoh, S.; Mochizuki, N.; Takekoshi, N.; Takano, H.; Nagai, T.; Komuro, I. A novel LIM protein Cal promotes cardiac differentiation by association with CSX/NKX2-5. J. Cell Biol. 2004, 164, 395-405. [CrossRef] [PubMed]

112. Voronova, A.; Al Madhoun, A.; Fischer, A.; Shelton, M.; Karamboulas, C.; Skerjanc, I.S. Gli2 and MEF2C activate each other's expression and function synergistically during cardiomyogenesis in vitro. Nucleic Acids Res. 2012, 40, 4723-4724. [CrossRef]

113. Behrens, A.N.; Iacovino, M.; Lohr, J.L.; Ren, Y.; Zierold, C.; Harvey, R.P.; Kyba, M.; Garry, D.J.; Martin, C.M. Nkx2-5 Mediates Differential Cardiac Differentiation Through Interaction with Hoxa10. Stem Cells Dev. 2013, 22, 2211-2220. [CrossRef]

114. Clark, C.D.; Lee, K.-H. Second heart field-specific expression of Nkx2-5 requires promoter proximal interaction with Srf. Mech. Dev. 2020, 162, 103615. [CrossRef]

115. Alexandrovich, A.; Arno, M.; Patient, R.K.; Shah, A.M.; Pizzey, J.A.; Brewer, A.C. Wnt2 is a direct downstream target of GATA6 during early cardiogenesis. Mech. Dev. 2006, 123, 297-311. [CrossRef]

116. Behrens, A.N.; Ren, Y.; Ferdous, A.; Garry, D.J.; Martin, C.M. Nkx2-5 Regulates Tdgf1 (Cripto) Early During Cardiac Development. J. Clin. Exp. Cardiol. 2013, 1, 1-4. [CrossRef]

117. Cambier, L.; Plate, M.; Sucov, H.M.; Pashmforoush, M. Nkx2-5 regulates cardiac growth through modulation of Wnt signaling by R-spondin3. Development 2014, 141, 2959-2971. [CrossRef]

118. Dodou, E.; Verzi, M.P.; Anderson, J.P.; Xu, S.-M.; Black, B.L. Mef2c is a direct transcriptional target of ISL1 and GATA factors in the anterior heart field during mouse embryonic development. Development 2004, 131, 3931-3942. [CrossRef] [PubMed]

119. Dorn, T.; Goedel, A.; Lam, J.T.; Haas, J.; Tian, Q.; Herrmann, F.; Bundschu, K.; Dobreva, G.; Schiemann, M.; Dirschinger, R.; et al. Direct Nkx2-5 Transcriptional Repression of Is11 Controls Cardiomyocyte Subtype Identity. Stem Cells 2015, 33, 1113-1129. [CrossRef]

120. Anderson, D.J.; Kaplan, D.I.; Bell, K.M.; Koutsis, K.; Haynes, J.M.; Mills, R.J.; Phelan, D.G.; Qian, E.L.; Leitoguinho, A.R.; Arasaratnam, D.; et al. NKX2-5 regulates human cardiomyogenesis via a HEY2 dependent transcriptional network. Nat. Commun. 2018, 9, 1-13. [CrossRef]

121. Horton, A.J.; Brooker, J.; Streitfeld, W.S.; Flessa, M.E.; Pillai, B.; Simpson, R.; Clark, C.D.; Gooz, M.B.; Sutton, K.K.; Foley, A.C.; et al. Nkx2-5 Second Heart Field Target Gene Ccdc117 Regulates DNA Metabolism and Proliferation. Sci. Rep. 2019, 9, 1-12. [CrossRef] [PubMed]

122. Liu, Z.-P.; Nakagawa, O.; Nakagawa, M.; Yanagisawa, H.; Passier, R.; Richardson, J.A.; Srivastava, D.; Olson, E.N. CHAMP, A Novel Cardiac-Specific Helicase Regulated by MEF2C. Dev. Biol. 2001, 234, 497-509. [CrossRef] 
123. Qian, L.; Wythe, J.D.; Liu, J.; Cartry, J.; Vogler, G.; Mohapatra, B.; Otway, R.T.; Huang, Y.; King, I.N.; Maillet, M.; et al. Tinman/Nkx2-5 acts via miR-1 and upstream of Cdc42 to regulate heart function across species. J. Cell Biol. 2011, 193, 1181-1196. [CrossRef] [PubMed]

124. Yu, B.; Gong, M.; Wang, Y.; Millard, R.W.; Pasha, Z.; Yang, Y.; Ashraf, M.; Xu, M. Cardiomyocyte Protection by GATA-4 Gene Engineered Mesenchymal Stem Cells Is Partially Mediated by Translocation of miR-221 in Microvesicles. PLoS ONE 2013, 8, e73304. [CrossRef]

125. Watt, A.J.; Battle, M.A.; Li, J.; Duncan, S.A. GATA4 is essential for formation of the proepicardium and regulates cardiogenesis. Proc. Natl. Acad. Sci. USA 2004, 101, 12573-12578. [CrossRef]

126. Zhou, B.; Von Gise, A.; Ma, Q.; Rivera-Feliciano, J.; Pu, W.T. Nkx2-5- and Isl1-expressing cardiac progenitors contribute to proepicardium. Biochem. Biophys. Res. Commun. 2008, 375, 450-453. [CrossRef]

127. Zeisberg, E.M.; Ma, Q.; Juraszek, A.L.; Moses, K.; Schwartz, R.J.; Izumo, S.; Pu, W.T. Morphogenesis of the right ventricle requires myocardial expression of Gata4. J. Clin. Investig. 2005, 115, 1522-1531. [CrossRef] [PubMed]

128. Moskowitz, I.P.; Kim, J.B.; Moore, M.L.; Wolf, C.M.; Peterson, M.A.; Shendure, J.; Nóbrega, M.A.; Yokota, Y.; Berul, C.; Izumo, S.; et al. A Molecular Pathway Including Id2, Tbx5, and Nkx2-5 Required for Cardiac Conduction System Development. Cell 2007, 129, 1365-1376. [CrossRef] [PubMed]

129. Espinoza-Lewis, R.A.; Liu, H.; Sun, C.; Chen, C.; Jiao, K.; Chen, Y.-P. Ectopic expression of Nkx2.5 suppresses the formation of the sinoatrial node in mice. Dev. Biol. 2011, 356, 359-369. [CrossRef]

130. Jay, P.Y.; Harris, B.S.; Maguire, C.T.; Buerger, A.; Wakimoto, H.; Tanaka, M.; Kupershmidt, S.; Roden, D.M.; Schultheiss, T.M.; O'Brien, T.X.; et al. Nkx2-5 mutation causes anatomic hypoplasia of the cardiac conduction system. J. Clin. Investig. 2004, 113, 1130-1137. [CrossRef] [PubMed]

131. Meysen, S.; Marger, L.; Hewett, K.W.; Jarry-Guichard, T.; Agarkova, I.; Chauvin, J.P.; Perriard, J.C.; Izumo, S.; Gourdie, R.G.; Mangoni, M.E.; et al. Nkx2.5 cell-autonomous gene function is required for the postnatal formation of the peripheral ventricular conduction system. Dev. Biol. 2007, 303, 740-753. [CrossRef]

132. Harris, B.S.; Spruill, L.; Edmonson, A.M.; Rackley, M.S.; Benson, D.W.; O’Brien, T.X.; Gourdie, R.G. Differentiation of cardiac Purkinje fibers requires precise spatiotemporal regulation of Nkx2-5 expression. Dev. Dyn. 2005, 235, 38-49. [CrossRef]

133. Biben, C.; Weber, R.; Kesteven, S.; Stanley, E.; McDonald, L.; Elliott, D.A.; Barnett, L.; Köentgen, F.; Robb, L.; Feneley, M.; et al. Cardiac Septal and Valvular Dysmorphogenesis in Mice Heterozygous for Mutations in the Homeobox GeneNkx2-5. Circ. Res. 2000, 87, 888-895. [CrossRef]

134. Tanaka, M.; Berul, C.; Ishii, M.; Jay, P.; Wakimoto, H.; Douglas, P.; Yamasaki, N.; Kawamoto, T.; Gehrmann, J.; Maguire, C.; et al. A Mouse Model of Congenital Heart Disease: Cardiac Arrhythmias and Atrial Septal Defect Caused by Haploinsufficiency of the Cardiac Transcription Factor Csx/Nkx2.5. Cold Spring Harb. Symp. Quant. Biol. 2002, 67, 317-326. [CrossRef]

135. Terada, R.; Warren, S.; Lu, J.T.; Chien, K.R.; Wessels, A.; Kasahara, H. Ablation of Nkx2-5 at mid-embryonic stage results in premature lethality and cardiac malformation. Cardiovasc. Res. 2011, 91, 289-299. [CrossRef] [PubMed]

136. Phan, D.; Rasmussen, T.L.; Nakagawa, O.; McAnally, J.; Gottlieb, P.D.; Tucker, P.W.; Richardson, J.A.; Bassel-Duby, R.; Olson, E.N. $\mathrm{BOP}$, a regulator of right ventricular heart development, is a direct transcriptional target of MEF2C in the developing heart. Development 2005, 132, 2669-2678. [CrossRef]

137. Liberatore, C.M.; Searcy-Schrick, R.D.; Yutzey, K.E. Ventricular Expression of tbx5 Inhibits Normal Heart Chamber Development. Dev. Biol. 2000, 223, 169-180. [CrossRef] [PubMed]

138. Koshiba-Takeuchi, K.; Mori, A.D.; Kaynak, B.L.; Cebra-Thomas, J.; Sukonnik, T.; Georges, R.O.; Latham, S.; Beck, L.; Henkelman, R.M.; Black, B.L.; et al. Reptilian heart development and the molecular basis of cardiac chamber evolution. Nature 2009, 461, 95-98. [CrossRef]

139. Zhang, K.K.; Xiang, M.; Zhou, L.; Liu, J.; Curry, N.; Heine, S.D.; Garcia-Pavia, P.; Zhang, X.; Wang, Q.; Xie, L. Gene network and familial analyses uncover a gene network involving Tbx5/Osr1/Pcsk6 interaction in the second heart field for atrial septation. Hum. Mol. Genet. 2016, 25, 1140-1151. [CrossRef] [PubMed]

140. Nadeaua, M.; Georges, R.O.; Laforest, B.; Yamak, A.; Lefebvre, C.; Beauregard, J.; Paradis, P.; Bruneau, B.G.; Andelfinger, G.; Nemer, M. An endocardial pathway involving Tbx5, Gata4, and Nos3 required for atrial septum formation. Proc. Natl. Acad. Sci. USA 2010, 107, 19356-19361. [CrossRef] [PubMed]

141. Xie, L.; Hoffmann, A.D.; Burnicka-Turek, O.; Friedland-Little, J.M.; Zhang, K.; Moskowitz, I.P. Tbx5-Hedgehog Molecular Networks Are Essential in the Second Heart Field for Atrial Septation. Dev. Cell 2012, 23, 280-291. [CrossRef]

142. Misra, C.; Chang, S.-W.; Basu, M.; Huang, N.; Garg, V. Disruption of myocardial Gata4 and Tbx5 results in defects in cardiomyocyte proliferation and atrioventricular septation. Hum. Mol. Genet. 2014, 23, 5025-5035. [CrossRef]

143. Campione, M.; Steinbeisser, H.; Schweickert, A.; Deissler, K.; Van Bebber, F.; A Lowe, L.; Nowotschin, S.; Viebahn, C.; Haffter, P.; Kuehn, M.R.; et al. The homeobox gene Pitx2: Mediator of asymmetric left-right signaling in vertebrate heart and gut looping. Development 1999, 126, 1225-1234.

144. Piedra, M.; Icardo, J.M.; Albajar, M.; Rodriguez-Rey, J.C.; A Ros, M. Pitx2 Participates in the Late Phase of the Pathway Controlling Left-Right Asymmetry. Cell 1998, 94, 319-324. [CrossRef]

145. Ryan, A.K.; Blumberg, B.; Rodriguez-Esteban, C.; Yonei-Tamura, S.; Tamura, K.; Tsukui, T.; De La Peña, J.; Sabbagh, W.; Greenwald, J.; Choe, S.; et al. Pitx2 determines left-right asymmetry of internal organs in vertebrates. Nat. Cell Biol. 1998, 394, 545-551. [CrossRef] [PubMed] 
146. Logan, M.; Pagán-Westphal, S.M.; Smith, D.M.; Paganessi, L.; Tabin, C.J. The Transcription Factor Pitx2 Mediates Situs-Specific Morphogenesis in Response to Left-Right Asymmetric Signals. Cell 1998, 94, 307-317. [CrossRef]

147. Yoshioka, H.; Meno, C.; Koshiba, K.; Sugihara, M.; Itoh, H.; Ishimaru, Y.; Inoue, T.; Ohuchi, H.; Semina, E.V.; Murray, J.C.; et al. Pitx2, a Bicoid-Type Homeobox Gene, Is Involved in a Lefty-Signaling Pathway in Determination of Left-Right Asymmetry. Cell 1998, 94, 299-305. [CrossRef]

148. Bisgrove, B.W.; Essner, J.J.; Yost, H.J. Multiple pathways in the midline regulate concordant brain, heart and gut left-right asymmetry. Development 2000, 127, 3567-3579. [PubMed]

149. Collins, M.M.; Maischein, H.-M.; Dufourcq, P.; Charpentier, M.; Blader, P.; Stainier, D.Y. Pitx2c orchestrates embryonic axis extension via mesendodermal cell migration. eLife 2018, 7, e34880. [CrossRef]

150. Dagle, J.; Sabel, J.L.; Littig, J.L.; Sutherland, L.B.; Kolker, S.J.; Weeks, D.L. Pitx2c attenuation results in cardiac defects and abnormalities of intestinal orientation in developing Xenopus laevis. Dev. Biol. 2003, 262, 268-281. [CrossRef]

151. Essner, J.J.; Branford, W.W.; Zhang, J.; Yost, H.J. Mesendoderm and left-right brain, heart and gut development are differentially regulated by pitx2 isoforms. Development 2000, 127, 1081-1093.

152. Gage, P.J.; Suh, H.; Camper, S.A. Dosage requirement of Pitx2 for development of multiple organs. Development 1999, 126, 4643-4651.

153. Yu, X.; Amand, T.R.S.; Wang, S.; Li, G.; Zhang, Y.; Hu, Y.P.; Nguyen, L.; Qiu, M.S.; Chen, Y.P. Differential expression and functional analysis of Pitx2 isoforms in regulation of heart looping in the chick. Development 2001, 128, 1005-1013. [PubMed]

154. Lu, M.-F.; Pressman, C.L.; Dyer, R.; Johnson, R.L.; Martin, J.F. Function of Rieger syndrome gene in left-right asymmetry and craniofacial development. Nat. Cell Biol. 1999, 401, 276-278. [CrossRef]

155. Kitamura, K.; Miura, H.; Miyagawa-Tomita, S.; Yanazawa, M.; Katoh-Fukui, Y.; Suzuki, R.; Ohuchi, H.; Suehiro, A.; Motegi, Y.; Nakahara, Y.; et al. Mouse Pitx2 deficiency leads to anomalies of the ventral body wall, heart, extra- and periocular mesoderm and right pulmonary isomerism. Development 1999, 126, 5749-5758.

156. Shiratori, H.; Yashiro, K.; Shen, M.M.; Hamada, H. Conserved regulation and role of Pitx2 in situs-specific morphogenesis of visceral organs. Development 2006, 133, 3015-3025. [CrossRef]

157. A Lowe, L.; Yamada, S.; Kuehn, M.R. Genetic dissection of nodal function in patterning the mouse embryo. Development 2001, 128, 1831-1843.

158. St Amand, T.R.; Ra, J.; Zhang, Y.; Hu, Y.; Baber, S.I.; Qiu, M.; Chen, Y. Cloning and expression pattern of chicken Pitx2: A new component in the SHH signaling pathway controlling embryonic heart looping. Biochem. Biophys. Res. Commun. 1998, 247, 100-105. [CrossRef] [PubMed]

159. Campione, M.; A Ros, M.; Icardo, J.M.; Piedra, E.; Christoffels, V.M.; Schweickert, A.; Blum, M.; Franco, D.; Moorman, A.F. Pitx2 Expression Defines a Left Cardiac Lineage of Cells: Evidence for Atrial and Ventricular Molecular Isomerism in the iv/iv Mice. Dev. Biol. 2001, 231, 252-264. [CrossRef]

160. Shiratori, H.; Sakuma, R.; Watanabe, M.; Hashiguchi, H.; Mochida, K.; Sakai, Y.; Nishino, J.; Saijoh, Y.; Whitman, M.; Hamada, $\mathrm{H}$. Two-step regulation of left-right asymmetric expression of Pitx2: Initiation by nodal signaling and maintenance by Nkx2. Mol. Cell. 2001, 7, 137-149. [CrossRef]

161. Campione, M.; Acosta, L.; Martinez, S.; Icardo, J.; Aranega, A.; Franco, D. Pitx2 and Cardiac Development: A Molecular Link between Left/Right Signaling and Congenital Heart Disease. Cold Spring Harb. Symp. Quant. Biol. 2002, 67, 89-95. [CrossRef]

162. Franco, D.; Campione, M. The role of Pitx2 during cardiac development. Linking left-right signaling and congenital heart diseases. Trends Cardiovasc. Med. 2003, 13, 157-163. [CrossRef]

163. Campione, M.; Franco, D. Current Perspectives in Cardiac Laterality. J. Cardiovasc. Dev. Dis. 2016, 3, 34. [CrossRef]

164. Franco, D.; Sedmera, D.; Lozano-Velasco, E. Multiple Roles of Pitx2 in Cardiac Development and Disease. J. Cardiovasc. Dev. Dis. 2017, 4, 16. [CrossRef] [PubMed]

165. Ai, D.; Liu, W.; Ma, L.; Dong, F.; Lu, M.-F.; Wang, D.; Verzi, M.P.; Cai, C.; Gage, P.J.; Evans, S.; et al. Pitx2 regulates cardiac left-right asymmetry by patterning second cardiac lineage-derived myocardium. Dev. Biol. 2006, 296, 437-449. [CrossRef]

166. Franco, D.; Campione, M.; Kelly, R.G.; Zammit, P.S.; Buckingham, M.; Lamers, W.H.; Moorman, A.F.M. Multiple transcriptional domains, with distinct left and right components, in the atrial chambers of the developing heart. Circ. Res. 2000, 87, 984-991. [CrossRef] [PubMed]

167. Mommersteeg, M.T.M.; Hoogaars, W.M.H.; Prall, O.W.J.; Vries, C.D.G.-D.; Wiese, C.; Clout, D.E.W.; Papaioannou, V.E.; Brown, N.A.; Harvey, R.P.; Moorman, A.F.M.; et al. Molecular Pathway for the Localized Formation of the Sinoatrial Node. Circ. Res. 2007, 100, 354-362. [CrossRef]

168. Ocaña, O.H.; Coskun, H.; Minguillón, C.; Murawala, P.; Tanaka, E.M.; Galcerán, J.; Muñoz-Chápuli, R.; Nieto, M.A. A right-handed signalling pathway drives heart looping in vertebrates. Nature 2017, 549, 86-90. [CrossRef]

169. Zeng, B.; Ren, X.-F.; Cao, F.; Zhou, X.-Y.; Zhang, J. Developmental patterns and characteristics of epicardial cell markers Tbx18 and Wt1 in murine embryonic heart. J. Biomed. Sci. 2011, 18, 67. [CrossRef]

170. Moore, A.W.; McInnes, L.; Kreidberg, J.; Hastie, N.D.; Schedl, A. YAC complementation shows a requirement for Wt1 in the development of epicardium, adrenal gland and throughout nephrogenesis. Development 1999, 126, $1845-1857$.

171. Acharya, A.; Baek, S.T.; Huang, G.; Eskiocak, B.; Goetsch, S.; Sung, C.Y.; Banfi, S.; Sauer, M.F.; Olsen, G.S.; Duffield, J.S.; et al. The bHLH transcription factor Tcf21 is required for lineage-specific EMT of cardiac fibroblast progenitors. Development 2012, 139, 2139-2149. [CrossRef] 
172. Ishii, Y.; Langberg, J.D.; Hurtado, R.; Lee, S.; Mikawa, T. Induction of proepicardial marker gene expression by the liver bud. Development 2007, 134, 3627-3637. [CrossRef]

173. Singh, R.; Hoogaars, W.M.; Barnett, P.; Grieskamp, T.; Rana, M.S.; Buermans, H.; Farin, H.F.; Petry, M.; Heallen, T.; Martin, J.F.; et al. Tbx2 and Tbx3 induce atrioventricular myocardial development and endocardial cushion formation. Cell Mol. Life Sci. 2012, 69, 1377-1389. [CrossRef]

174. Christoffels, V.M.; Hoogaars, W.M.; Tessari, A.; Clout, D.E.; Moorman, A.F.M.; Campione, M. T-box transcription factor Tbx2 represses differentiation and formation of the cardiac chambers. Dev. Dyn. 2004, 229, 763-770. [CrossRef]

175. Sedletcaia, A.; Evans, T. Heart chamber size in zebrafish is regulated redundantly by duplicated tbx2 genes. Dev. Dyn. 2011, 240, 1548-1557. [CrossRef]

176. Chi, N.C.; Shaw, R.M.; De Val, S.; Kang, G.; Jan, L.Y.; Black, B.L.; Stainier, D.Y. Foxn4 directly regulates tbx2b expression and atrioventricular canal formation. Genes Dev. 2008, 22, 734-739. [CrossRef]

177. Shirai, M.; Imanaka-Yoshida, K.; Schneider, M.D.; Schwartz, R.J.; Morisaki, T. T-box 2, a mediator of Bmp-Smad signaling, induced hyaluronan synthase 2 and Tgfbeta2 expression and endocardial cushion formation. Proc. Natl. Acad. Sci. USA 2009, 106, 18604-18609. [CrossRef]

178. Dupays, L.; Kotecha, S.; Angst, B.; Mohun, T.J. Tbx2 misexpression impairs deployment of second heart field derived progenitor cells to the arterial pole of the embryonic heart. Dev. Biol. 2009, 333, 121-131. [CrossRef] [PubMed]

179. Hoogaars, W.M.; Tessari, A.; Moorman, A.F.; de Boer, P.A.; Hagoort, J.; Soufan, A.T.; Campione, M.; Christoffels, V.M. The transcriptional repressor Tbx3 delineates the developing central conduction system of the heart. Cardiovasc. Res. 2004, 62, 489-499. [CrossRef]

180. Mesbah, K.; Harrelson, Z.; Théveniau-Ruissy, M.; Papaioannou, V.E.; Kelly, R.G. Tbx3 Is Required for Outflow Tract Development. Circ. Res. 2008, 103, 743-750. [CrossRef]

181. Mohan, R.A.; Mommersteeg, M.T.M.; Domínguez, J.N.; Choquet, C.; Wakker, V.; de Gier-de Vries, C.; Boink, G.J.J.; Boukens, B.J.; Miquerol, L.; Verkerk, A.O.; et al. Embryonic Tbx3+ cardiomyocytes form the mature cardiac conduction system by progressive fate restriction. Development 2018, 145, dev167361. [CrossRef]

182. Mohan, R.A.; Bosada, F.M.; Van Weerd, J.H.; Van Duijvenboden, K.; Wang, J.; Mommersteeg, M.T.; Hooijkaas, I.B.; Wakker, V.; Vries, C.D.G.-D.; Coronel, R.; et al. T-box transcription factor 3 governs a transcriptional program for the function of the mouse atrioventricular conduction system. Proc. Natl. Acad. Sci. USA 2020, 117, 18617-18626. [CrossRef] [PubMed]

183. Cai, X.; Nomura-Kitabayashi, A.; Cai, W.; Yan, J.; Christoffels, V.M.; Cai, C.-L. Myocardial Tbx20 regulates early atrioventricular canal formation and endocardial epithelial-mesenchymal transition via Bmp2. Dev. Biol. 2011, 360, 381-390. [CrossRef]

184. Singh, M.K.; Christoffels, V.M.; Dias, J.M.; Trowe, M.-O.; Petry, M.; Schuster-Gossler, K.; Bürger, A.; Ericson, J.; Kispert, A. Tbx20 is essential for cardiac chamber differentiation and repression of Tbx2. Development 2005, 132, 2697-2707. [CrossRef]

185. Singh, R.; Horsthuis, T.; Farin, H.F.; Grieskamp, T.; Norden, J.; Petry, M.; Wakker, V.; Moorman, A.F.M.; Christoffels, V.M.; Kispert, A. Tbx20 Interacts With Smads to Confine Tbx2 Expression to the Atrioventricular Canal. Circ. Res. 2009, 105, 442-452. [CrossRef]

186. Stennard, F.A.; Costa, M.W.; Lai, D.; Biben, C.; Furtado, M.B.; Solloway, M.J.; McCulley, D.J.; Leimena, C.; Preis, J.I.; Dunwoodie, S.L.; et al. Murine T-box transcription factor Tbx20 acts as a repressor during heart development, and is essential for adult heart integrity, function and adaptation. Development 2005, 132, 2451-2462. [CrossRef]

187. Chakraborty, S.; Yutzey, K.E. Tbx20 regulation of cardiac cell proliferation and lineage specialization during embryonic and fetal development in vivo. Dev. Biol. 2012, 363, 234-246. [CrossRef] [PubMed]

188. Greulich, F.; Rudat, C.; Kispert, A. Mechanisms of T-box gene function in the developing heart. Cardiovasc. Res. 2011, 91, 212-222. [CrossRef] [PubMed]

189. Plageman, T.F.; Yutzey, K.E. T-box genes and heart development: Putting the "T" in heart. Dev. Dyn. 2005, 232, 11-20. [CrossRef]

190. Cai, C.-L.; Zhou, W.; Yang, L.; Bu, L.; Qyang, Y.; Zhang, X.; Li, X.; Rosenfeld, M.G.; Chen, J.; Evans, S.M. T-box genes coordinate regional rates of proliferation and regional specification during cardiogenesis. Development 2005, 132, 2475-2487. [CrossRef]

191. Christoffels, V.M.; Keijser, A.G.; Houweling, A.C.; Clout, D.E.; Moorman, A.F. Patterning the Embryonic Heart: Identification of Five Mouse Iroquois Homeobox Genes in the Developing Heart. Dev. Biol. 2000, 224, 263-274. [CrossRef] [PubMed]

192. Kim, K.-H.; Rosen, A.; Bruneau, B.G.; Hui, C.-C.; Backx, P.H. Iroquois Homeodomain Transcription Factors in Heart Development and Function. Circ. Res. 2012, 110, 1513-1524. [CrossRef]

193. Bruneau, B.G.; Bao, Z.-Z.; Tanaka, M.; Schott, J.-J.; Izumo, S.; Cepko, C.L.; Seidman, J.; Seidman, C.E. Cardiac Expression of the Ventricle-Specific Homeobox Gene Irx4 Is Modulated by Nkx2-5 and dHand. Dev. Biol. 2000, 217, 266-277. [CrossRef]

194. Kokubo, H.; Miyagawa-Tomita, S.; Nakazawa, M.; Saga, Y.; Johnson, R.L. Mouse hesr1 and hesr2 genes are redundantly required to mediate Notch signaling in the developing cardiovascular system. Dev. Biol. 2005, 278, 301-309. [CrossRef]

195. Kokubo, H.; Tomita-Miyagawa, S.; Hamada, Y.; Saga, Y. Hesr1 and Hesr2 regulate atrioventricular boundary formation in the developing heart through the repression of Tbx2. Development 2007, 134, 747-755. [CrossRef]

196. Rutenberg, J.B.; Fischer, A.; Jia, H.; Gessler, M.; Zhong, T.P.; Mercola, M. Developmental patterning of the cardiac atrioventricular canal by Notch and Hairy-related transcription factors. Development 2006, 133, 4381-4390. [CrossRef] [PubMed]

197. Koibuchi, N.; Chin, M.T. CHF1/Hey2 Plays a Pivotal Role in Left Ventricular Maturation Through Suppression of Ectopic Atrial Gene Expression. Circ. Res. 2007, 100, 850-855. [CrossRef]

198. Pereira, F.A.; Qiu, Y.; Zhou, G.; Tsai, M.-J.; Tsai, S.Y. The orphan nuclear receptor COUP-TFII is required for angiogenesis and heart development. Genes Dev. 1999, 13, 1037-1049. [CrossRef] [PubMed] 
199. Srivastava, D.; Cserjesi, P.; Olson, E.N. A Subclass of bHLH Proteins Required for Cardiac Morphogenesis. Science 1995, 270, 1995-1999. [CrossRef]

200. Srivastava, D.; Thomas, T.; Lin, Q.; Kirby, M.L.; Brown, R.; Olson, E.N. Regulation of cardiac mesodermal and neural crest development by the bHLH transcription factor, dHAND. Nat. Genet. 1997, 16, 154-160. [CrossRef]

201. Togi, K.; Kawamoto, T.; Yamauchi, R.; Yoshida, Y.; Kita, T.; Tanaka, M. Role of Hand1/eHAND in the Dorso-Ventral Patterning and Interventricular Septum Formation in the Embryonic Heart. Mol. Cell. Biol. 2004, 24, 4627-4635. [CrossRef] [PubMed]

202. Yamagishi, H.; Yamagishi, C.; Nakagawa, O.; Harvey, R.P.; Olson, E.N.; Srivastava, D. The combinatorial activities of Nkx2.5 and dHAND are essential for cardiac ventricle formation. Dev. Biol. 2001, 239, 190-203. [CrossRef]

203. Bolte, C.; Zhang, Y.; Wang, I.-C.; Kalin, T.V.; Molkentin, J.D.; Kalinichenko, V.V. Expression of Foxm1 Transcription Factor in Cardiomyocytes Is Required for Myocardial Development. PLoS ONE 2011, 6, e22217. [CrossRef]

204. Chen, F.; Kook, H.; Milewski, R.; Gitler, A.D.; Lu, M.M.; Li, J.; Nazarian, R.; Schnepp, R.; Jen, K.; Biben, C.; et al. Hop Is an Unusual Homeobox Gene that Modulates Cardiac Development. Cell 2002, 110, 713-723. [CrossRef]

205. Lavallée, G.; Andelfinger, G.; Nadeau, M.; Lefebvre, C.; Nemer, G.; E Horb, M.; Nemer, M. The Kruppel-like transcription factor KLF13 is a novel regulator of heart development. EMBO J. 2006, 25, 5201-5213. [CrossRef]

206. Niu, Z.; Yu, W.; Zhang, S.X.; Barron, M.; Belaguli, N.S.; Schneider, M.D.; Parmacek, M.; Nordheim, A.; Schwartz, R.J. Conditional Mutagenesis of the Murine Serum Response Factor Gene Blocks Cardiogenesis and the Transcription of Downstream Gene Targets. J. Biol. Chem. 2005, 280, 32531-32538. [CrossRef]

207. Parlakian, A.; Tuil, D.; Hamard, G.; Tavernier, G.; Hentzen, D.; Concordet, J.-P.; Paulin, D.; Li, Z.; Daegelen, D. Targeted Inactivation of Serum Response Factor in the Developing Heart Results in Myocardial Defects and Embryonic Lethality. Mol. Cell. Biol. 2004, 24, 5281-5289. [CrossRef] [PubMed]

208. Espinoza-Lewis, R.A.; Yu, L.; He, F.; Liu, H.; Tang, R.; Shi, J.; Sun, X.; Martin, J.F.; Wang, D.; Yang, J.; et al. Shox2 is essential for the differentiation of cardiac pacemaker cells by repressing Nkx2-5. Dev. Biol. 2009, 327, 376-385. [CrossRef] [PubMed]

209. Hu, W.; Xin, Y.; Zhao, Y.; Hu, J. Shox2: The Role in Differentiation and Development of Cardiac Conduction System. Tohoku J. Exp. Med. 2018, 244, 177-186. [CrossRef] [PubMed]

210. Ye, W.; Wang, J.; Song, Y.; Yu, D.; Sun, C.; Liu, C.; Chen, F.; Zhang, Y.; Wang, F.; Harvey, R.P.; et al. A common Shox2-Nkx2-5 antagonistic mechanism primes the pacemaker cell fate in the pulmonary vein myocardium and sinoatrial node. Development 2015, 142, 2521-2532. [CrossRef]

211. Liu, H.; Espinoza-Lewis, R.A.; Chen, C.; Hu, X.; Zhang, Y.; Chen, Y.-P. The Role of Shox2 in SAN Development and Function. Pediatr. Cardiol. 2012, 33, 882-889. [CrossRef]

212. Liu, H.; Chen, C.-H.; Espinoza-Lewis, R.A.; Jiao, Z.; Sheu, I.; Hu, X.; Lin, M.; Zhang, Y.; Chen, Y.-P. Functional Redundancy between HumanSHOXand MouseShox2Genes in the Regulation of Sinoatrial Node Formation and Pacemaking Function. J. Biol. Chem. 2011, 286, 17029-17038. [CrossRef]

213. Blaschke, R.J.; Hahurij, N.D.; Kuijper, M.S.; Just, S.; Wisse, L.J.; Deissler, K.; Maxelon, T.; Anastassiadis, K.; Spitzer, J.; Hardt, S.E.; et al. Targeted Mutation Reveals Essential Functions of the Homeodomain Transcription Factor Shox2 in Sinoatrial and Pacemaking Development. Circulation 2007, 115, 1830-1838. [CrossRef]

214. Wang, Q.; Lan, Y.; Cho, E.-S.; Maltby, K.M.; Jiang, R. Odd-skipped related 1 (Odd1) is an essential regulator of heart and urogenital development. Dev. Biol. 2005, 288, 582-594. [CrossRef]

215. Chiplunkar, A.R.; Lung, T.K.; Alhashem, Y.; Koppenhaver, B.A.; Salloum, F.N.; Kukreja, R.C.; Haar, J.L.; Lloyd, J.A. Krüppel-Like Factor 2 Is Required for Normal Mouse Cardiac Development. PLoS ONE 2013, 8, e54891. [CrossRef]

216. Gawdzik, J.C.; Yue, M.S.; Martin, N.R.; Elemans, L.M.; Lanham, K.A.; Heideman, W.; Rezendes, R.; Baker, T.R.; Taylor, M.R.; Plavicki, J.S. sox9b is required in cardiomyocytes for cardiac morphogenesis and function. Sci. Rep. 2018, 8, 13906. [CrossRef]

217. Moskowitz, I.P.; Wang, J.; Peterson, M.A.; Pu, W.T.; MacKinnon, A.C.; Oxburgh, L.; Chu, G.C.; Sarkar, M.; Berul, C.; Smoot, L.; et al. Transcription factor genes Smad4 and Gata4 cooperatively regulate cardiac valve development. Proc. Natl. Acad. Sci. USA 2011, 108, 4006-4011. [CrossRef] [PubMed]

218. Lindsay, E.A.; Vitelli, F.; Su, H.; Morishima, M.; Huynh, T.; Pramparo, T.; Jurecic, V.; Ogunrinu, G.; Sutherland, H.F.; Scambler, P.J.; et al. Tbx1 haploinsufficieny in the DiGeorge syndrome region causes aortic arch defects in mice. Nature 2001, 410, 97-101. [CrossRef] [PubMed]

219. Kume, T.; Jiang, H.; Topczewska, J.M.; Hogan, B.L. The murine winged helix transcription factors, Foxc1 and Foxc2, are both required for cardiovascular development and somitogenesis. Genes Dev. 2001, 15, 2470-2482. [CrossRef] [PubMed]

220. Bergwerff, M.; Groot, A.G.-D.; Wisse, L.J.; DeRuiter, M.C.; Wessels, A.; Martin, J.F.; Olson, E.N.; Kern, M.J. Loss of function of the Prx1 and Prx2 homeobox genes alters architecture of the great elastic arteries and ductus arteriosus. Virchows Arch. 2000, 436, 12-19. [CrossRef] [PubMed]

221. Oka, T.; Xu, J.; Molkentin, J.D. Re-employment of developmental transcription factors in adult heart disease. Semin. Cell Dev. Biol. 2007, 18, 117-131. [CrossRef]

222. Hamada, H. Molecular and cellular basis of left-right asymmetry in vertebrates. Proc. Jpn. Acad. Ser. B Phys. Biol. Sci. 2020, 96, 273-296. [CrossRef]

223. Chazaud, C.; Chambon, P.; Dollé, P. Retinoic acid is required in the mouse embryo for left-right asymmetry determination and heart morphogenesis. Development 1999, 126, 2589-2596. 
224. Zile, M.H.; Kostetskii, I.; Yuan, S.; Kostetskaia, E.; Amand, T.R.S.; Chen, Y.; Jiang, W. Retinoid Signaling Is Required to Complete the Vertebrate Cardiac Left/Right Asymmetry Pathway. Dev. Biol. 2000, 223, 323-338. [CrossRef]

225. Yamauchi, H.; Miyakawa, N.; Miyake, A.; Itoh, N. Fgf4 is required for left-right patterning of visceral organs in zebrafish. Dev. Biol. 2009, 332, 177-185. [CrossRef] [PubMed]

226. Meyers, E.N.; Martin, G.R. Differences in left-right axis pathways in mouse and chick: Functions of FGF8 and SHH. Science 1999, 285, 403-406. [CrossRef] [PubMed]

227. Fischer, A.; Viebahn, C.; Blum, M. FGF8 Acts as a Right Determinant during Establishment of the Left-Right Axis in the Rabbit. Curr. Biol. 2002, 12, 1807-1816. [CrossRef]

228. Hashimoto, H.; Rebagliati, M.; Ahmad, N.; Muraoka, O.; Kurokawa, T.; Hibi, M.; Suzuki, T. The Cerberus/Dan-family protein Charon is a negative regulator of Nodal signaling during left-right patterning in zebrafish. Development 2004, 131, 1741-1753. [CrossRef]

229. Monteiro, R.; Van Dinther, M.; Bakkers, J.; Wilkinson, R.N.; Patient, R.; Dijke, P.T.; Mummery, C. Two novel type II receptors mediate BMP signalling and are required to establish left-right asymmetry in zebrafish. Dev. Biol. 2008, 315, 55-71. [CrossRef]

230. Meno, C.; Shimono, A.; Saijoh, Y.; Yashiro, K.; Mochida, K.; Ohishi, S.; Noji, S.; Kondoh, H.; Hamada, H. lefty-1 is required for left-right determination as a regulator of lefty-2 and nodal. Cell 1998, 94, 287-297. [CrossRef]

231. Chen, Y.; Mironova, E.; Whitaker, L.L.; Edwards, L.; Yost, H.J.; Ramsdell, A.F. ALK4 functions as a receptor for multiple TGF beta-related ligands to regulate left-right axis determination and mesoderm induction in Xenopus. Dev. Biol. 2004, 268, 280-294. [CrossRef]

232. Branford, W.W.; Essner, J.J.; Yost, H. Regulation of Gut and Heart Left-Right Asymmetry by Context-Dependent Interactions between Xenopus Lefty and BMP4 Signaling. Dev. Biol. 2000, 223, 291-306. [CrossRef]

233. Chang, H.; Zwijsen, A.; Vogel, H.; Huylebroeck, D.; Matzuk, M.M.; Vogel, H. Smad5 Is Essential for Left-Right Asymmetry in Mice. Dev. Biol. 2000, 219, 71-78. [CrossRef]

234. Tsiairis, C.; McMahon, A.P. An Hh-Dependent Pathway in Lateral Plate Mesoderm Enables the Generation of Left/Right Asymmetry. Curr. Biol. 2009, 19, 1912-1917. [CrossRef]

235. Yang, F.; Qi, J. miR-430a regulates the development of left-right asymmetry by targeting sqt in the teleost. Gene 2020, 745, 144628. [CrossRef] [PubMed]

236. Heigwer, J.; Kutzner, J.; Haeussler, M.; Burkhalter, M.D.; Draebing, T.; Juergensen, L.; Katus, H.A.; Philipp, M.; Westhoff, J.H.; Hassel, D. miR-103/107 regulates left-right asymmetry in zebrafish by modulating Kupffer's vesicle development and ciliogenesis. Biochem. Biophys. Res. Commun. 2020, 527, 432-439. [CrossRef] [PubMed]

237. Hatayama, M.; Mikoshiba, K.; Aruga, J. IP3 signaling is required for cilia formation and left-right body axis determination in Xenopus embryos. Biochem. Biophys. Res. Commun. 2011, 410, 520-524. [CrossRef]

238. Lin, C.-Y.; Tsai, M.-Y.; Liu, Y.-H.; Lu, Y.-F.; Chen, Y.-C.; Lai, Y.-R.; Liao, H.-C.; Lien, H.-W.; Yang, C.-H.; Huang, C.-J.; et al. Klf8 regulates left-right asymmetric patterning through modulation of Kupffer's vesicle morphogenesis and spaw expression. J. Biomed. Sci. 2017, 24, 45. [CrossRef] [PubMed]

239. Rankin, C.T.; Bunton, T.; Lawler, A.M.; Lee, S.-J. Regulation of left-right patterning in mice by growth/differentiation factor-1. Nat. Genet. 2000, 24, 262-265. [CrossRef] [PubMed]

240. Tamakoshi, T.; Itakura, T.; Chandra, A.; Uezato, T.; Yang, Z.; Xue, X.-D.; Wang, B.; Hackett, B.P.; Yokoyama, T.; Miura, N. Roles of the Foxj1 and Inv genes in the left-right determination of internal organs in mice. Biochem. Biophys. Res. Commun. 2006, 339, 932-938. [CrossRef] [PubMed]

241. Gormley, J.P.; Nascone-Yoder, N.M. Left and right contributions to the Xenopus heart: Implications for asymmetric morphogenesis. Dev. Genes Evol. 2003, 213, 390-398. [CrossRef]

242. Walton, R.Z.; Bruce, A.E.; Olivey, H.E.; Najib, K.; Johnson, V.; Earley, J.U.; Ho, R.K.; Svensson, E.C. Fog1 is required for cardiac looping in zebrafish. Dev. Biol. 2006, 289, 482-493. [CrossRef]

243. Duboc, V.; Röttinger, E.; Lapraz, F.; Besnardeau, L.; Lepage, T. Left-Right Asymmetry in the Sea Urchin Embryo Is Regulated by Nodal Signaling on the Right Side. Dev. Cell 2005, 9, 147-158. [CrossRef] [PubMed]

244. Long, S.; Ahmad, N.; Rebagliati, M. Zebrafish Hearts and Minds: Nodal Signaling in Cardiac and Neural Left-Right Asymmetry. Cold Spring Harb. Symp. Quant. Biol. 2002, 67, 27-36. [CrossRef]

245. Chin, A.J.; Tsang, M.; Weinberg, E.S. Heart and Gut Chiralities Are Controlled Independently from Initial Heart Position in the Developing Zebrafish. Dev. Biol. 2000, 227, 403-421. [CrossRef] [PubMed]

246. Schneider, A.; Mijalski, T.; Schlange, T.; Dai, W.; Overbeek, P.A.; Arnold, H.-H.; Brand, T. The homeobox gene it NKX3.2 is a target of left-right signalling and is expressed on opposite sides in chick and mouse embryos. Curr. Biol. 1999, 9, 911-914. [CrossRef]

247. Soukup, V. Left-right asymmetry specification in amphioxus: Review and prospects. Int. J. Dev. Biol. 2017, 61, 611-620. [CrossRef]

248. Tadjuidje, E.; Kofron, M.; Mir, A.; Wylie, C.; Heasman, J.; Cha, S.-W. Nodal signalling in Xenopus: The role of Xnr5 in left/right asymmetry and heart development. Open Biol. 2016, 6, 150187. [CrossRef]

249. Hamada, H.; Meno, C.; Saijoh, Y.; Adachi, H.; Yashiro, K.; Sakuma, R.; Shiratori, H. Role of asymmetric signals in left-right patterning in the mouse. Am. J. Med. Genet. 2001, 101, 324-327. [CrossRef]

250. Boorman, C.J.; Shimeld, S.M. The evolution of left-right asymmetry in chordates. BioEssays 2002, 24, 1004-1011. [CrossRef]

251. Grimes, D.T.; Burdine, R.D. Left-Right Patterning: Breaking Symmetry to Asymmetric Morphogenesis. Trends Genet. 2017, 33, 616-628. [CrossRef] [PubMed] 
252. Rago, L.; Castroviejo, N.; Fazilaty, H.; Garcia-Asencio, F.; Ocaña, O.H.; Galcerán, J.; Nieto, M.A. MicroRNAs Establish the Right-Handed Dominance of the Heart Laterality Pathway in Vertebrates. Dev. Cell 2019, 51, 446-459.e5. [CrossRef]

253. Dasgupta, A.; Amack, J.D. Cilia in vertebrate left-right patterning. Philos. Trans. R. Soc. Lond. B Biol. Sci. 2016, $371,20150410$. [CrossRef]

254. Blum, M.; Vick, P. Left-Right Asymmetry: Cilia and Calcium Revisited. Curr. Biol. 2015, 25, R205-R207. [CrossRef]

255. Ferreira, R.R.; Pakula, G.; Klaeyle, L.; Fukui, H.; Vilfan, A.; Supatto, W.; Vermot, J. Chiral Cilia Orientation in the Left-Right Organizer. Cell Rep. 2018, 25, 2008-2016.e4. [CrossRef]

256. Shinohara, K.; Hamada, H. Cilia in Left-Right Symmetry Breaking. Cold Spring Harb. Perspect. Biol. 2017, 9, a028282. [CrossRef]

257. Chien, Y.-H.; Srinivasan, S.; Keller, R.; Kintner, C. Mechanical Strain Determines Cilia Length, Motility, and Planar Position in the Left-Right Organizer. Dev. Cell 2018, 45, 316-330.e4. [CrossRef]

258. Yoshiba, S.; Hamada, H. Roles of cilia, fluid flow, and Ca2+ signaling in breaking of left-right symmetry. Trends Genet. 2014, 30, 10-17. [CrossRef]

259. Takemoto, A.; Miyamoto, T.; Simono, F.; Kurogi, N.; Shirae-Kurabayashi, M.; Awazu, A.; Suzuki, K.-I.T.; Yamamoto, T.; Sakamoto, N. Cilia play a role in breaking left-right symmetry of the sea urchin embryo. Genes Cells 2016, 21, 568-578. [CrossRef]

260. Zhu, X.; Shi, C.; Zhong, Y.; Liu, X.; Yan, Q.; Wu, X.; Wang, Y.; Li, G. Cilia-driven asymmetric Hedgehog signalling determines the amphioxus left-right axis by controlling Dand5 expression. Development 2020, 147, dev182469. [CrossRef]

261. Yuan, S.; Brueckner, M. Visualization and Manipulation of Cilia and Intraciliary Calcium in the Zebrafish Left-Right Organizer. Methods Mol Biol. 2016, 1454, 123-147. [CrossRef]

262. Pereira, R.; Barbosa, T.; Gales, L.; Oliveira, E.; Santos, R.; Oliveira, J.; Sousa, M. Clinical and Genetic Analysis of Children with Kartagener Syndrome. Cells 2019, 8, 900. [CrossRef]

263. Yue, Y.; Huang, Q.; Zhu, P.; Zhao, P.; Tan, X.; Liu, S.; Li, S.; Han, X.; Cheng, L.; Li, B.; et al. Identification of Pathogenic Mutations and Investigation of the NOTCH Pathway Activation in Kartagener Syndrome. Front. Genet. 2019, 10, 749. [CrossRef]

264. Bellchambers, H.M.; Ware, S.M. ZIC3 in Heterotaxy. Adv. Exp. Med. Biol. 2018, 1046, 301-327. [CrossRef]

265. Horváth, J.; Fliegauf, M.; Olbrich, H.; Kispert, A.; King, S.M.; Mitchison, H.; Zariwala, M.A.; Knowles, M.R.; Sudbrak, R.; Fekete, G.; et al. Identification and Analysis of Axonemal Dynein Light Chain 1 in Primary Ciliary Dyskinesia Patients. Am. J. Respir. Cell Mol. Biol. 2005, 33, 41-47. [CrossRef]

266. Mazor, M.; Alkrinawi, S.; Chalifa-Caspi, V.; Manor, E.; Sheffield, V.C.; Aviram, M.; Parvari, R. Primary Ciliary Dyskinesia Caused by Homozygous Mutation in DNAL1, Encoding Dynein Light Chain 1. Am. J. Hum. Genet. 2011, 88, 599-607. [CrossRef]

267. Loges, N.T.; Olbrich, H.; Fenske, L.; Mussaffi, H.; Horvath, J.; Fliegauf, M.; Kuhl, H.; Baktai, G.; Peterffy, E.; Chodhari, R.; et al. DNAI2 Mutations Cause Primary Ciliary Dyskinesia with Defects in the Outer Dynein Arm. Am. J. Hum. Genet. 2008, 83, 547-558. [CrossRef]

268. Olbrich, H.; Häffner, K.; Kispert, A.; Völkel, A.; Volz, A.; Sasmaz, G.; Reinhardt, R.; Hennig, S.; Lehrach, H.; Konietzko, N.; et al. Mutations in DNAH5 cause primary ciliary dyskinesia and randomization of left-right asymmetry. Nat. Genet. 2002, 30, 143-144. [CrossRef] [PubMed]

269. Dougherty, G.W.; Loges, N.T.; Klinkenbusch, J.A.; Olbrich, H.; Pennekamp, P.; Menchen, T.; Raidt, J.; Wallmeier, J.; Werner, C.; Westermann, C.; et al. DNAH11 Localization in the Proximal Region of Respiratory Cilia Defines Distinct Outer Dynein Arm Complexes. Am. J. Respir. Cell Mol. Biol. 2016, 55, 213-224. [CrossRef]

270. Li, Y.; Yagi, H.; Onuoha, E.O.; Damerla, R.R.; Francis, R.; Furutani, Y.; Tariq, M.; King, S.M.; Hendricks, G.; Cui, C.; et al. DNAH6 and Its Interactions with PCD Genes in Heterotaxy and Primary Ciliary Dyskinesia. PLoS Genet. 2016, 12, e1005821. [CrossRef]

271. Loges, N.T.; Olbrich, H.; Becker-Heck, A.; Häffner, K.; Heer, A.; Reinhard, C.; Schmidts, M.; Kispert, A.; Zariwala, M.A.; Leigh, M.W.; et al. Deletions and Point Mutations of LRRC50 Cause Primary Ciliary Dyskinesia Due to Dynein Arm Defects. Am. J. Hum. Genet. 2009, 85, 883-889. [CrossRef]

272. Merveille, A.C.; Davis, E.E.; Becker-Heck, A.; Legendre, M.; Amirav, I.; Bataille, G.; Belmont, J.; Beydon, N.; Billen, F.; Clément, A.; et al. CCDC39 is required for assembly of inner dynein arms and the dynein regulatory complex and for normal ciliary motility in humans and dogs. Nat. Genet. 2011, 43, 72-78. [CrossRef]

273. Wallmeier, J.; Shiratori, H.; Dougherty, G.W.; Edelbusch, C.; Hjeij, R.; Loges, N.T.; Menchen, T.; Olbrich, H.; Pennekamp, P.; Raidt, J.; et al. TTC25 Deficiency Results in Defects of the Outer Dynein Arm Docking Machinery and Primary Ciliary Dyskinesia with Left-Right Body Asymmetry Randomization. Am. J. Hum. Genet. 2016, 99, 460-469. [CrossRef]

274. Hirokawa, N.; Tanaka, Y.; Okada, Y. Left-Right Determination: Involvement of Molecular Motor KIF3, Cilia, and Nodal Flow. Cold Spring Harb. Perspect. Biol. 2009, 1, a000802. [CrossRef]

275. Jahr, M.; Schlueter, J.; Brand, T.; Männer, J. Development of the proepicardium in Xenopus laevis. Dev. Dyn. 2008, 237, 3088-3096. [CrossRef]

276. Niderla-Bielińska, J.; Jankowska-Steifer, E.; Flaht-Zabost, A.; Gula, G.; Czarnowska, E.; Ratajska, A. Proepicardium: Current Understanding of its Structure, Induction, and Fate. Anat. Rec. Adv. Integr. Anat. Evol. Biol. 2019, 302, 893-903. [CrossRef]

277. Maya-Ramos, L.; Cleland, J.; Bressan, M.; Mikawa, T. Induction of the Proepicardium. J. Dev. Biol. 2013, 1, 82-91. [CrossRef]

278. Niderla-Bielińska, J.; Ciszek, B.; Jankowska-Steifer, E.; Flaht-Zabost, A.; Gula, G.; Radomska-Leśniewska, D.M.; Ratajska, A. Mouse Proepicardium Exhibits a Sprouting Response to Exogenous Proangiogenic Growth Factors in vitro. J. Vasc. Res. 2016, 53, 83-93. [CrossRef] 
279. Rodgers, L.S.; Lalani, S.; Runyan, R.B.; Camenisch, T.D. Differential growth and multicellular villi direct proepicardial translocation to the developing mouse heart. Dev. Dyn. 2008, 237, 145-152. [CrossRef]

280. Nahirney, P.C.; Mikawa, T.; Fischman, D.A. Evidence for an extracellular matrix bridge guiding proepicardial cell migration to the myocardium of chick embryos. Dev. Dyn. 2003, 227, 511-523. [CrossRef]

281. Plavicki, J.S.; Hofsteen, P.; Yue, M.S.; A Lanham, K.; Peterson, R.E.; Heideman, W. Multiple modes of proepicardial cell migration require heartbeat. BMC Dev. Biol. 2014, 14, 18. [CrossRef]

282. Schlueter, J.; Männer, J.; Brand, T. BMP is an important regulator of proepicardial identity in the chick embryo. Dev. Biol. 2006, 295, 546-558. [CrossRef]

283. Liu, J.; Stainier, D.Y. Tbx5 and Bmp Signaling Are Essential for Proepicardium Specification in Zebrafish. Circ. Res. 2010, 106, 1818-1828. [CrossRef]

284. Ishii, Y.; Garriock, R.J.; Navetta, A.M.; Coughlin, L.E.; Mikawa, T. BMP Signals Promote Proepicardial Protrusion Necessary for Recruitment of Coronary Vessel and Epicardial Progenitors to the Heart. Dev. Cell 2010, 19, 307-316. [CrossRef]

285. Andrés-Delgado, L.; Ernst, A.; Galardi-Castilla, M.; Bazaga, D.; Peralta, M.; Münch, J.; González-Rosa, J.M.; Marques, I.; Tessadori, F.; De La Pompa, J.L.; et al. Actin dynamics and the Bmp pathway drive apical extrusion of proepicardial cells. Development 2019, 146, dev174961. [CrossRef]

286. Andrés-Delgado, L.; Galardi-Castilla, M.; Münch, J.; Peralta, M.; Ernst, A.; González-Rosa, J.M.; Tessadori, F.; Santamaría, L.; Bakkers, J.; Vermot, J.; et al. Notch and Bmp signaling pathways act coordinately during the formation of the proepicardium. Dev. Dyn. 2020, 249, 1455-1469. [CrossRef]

287. Schlueter, J.; Brand, T. A right-sided pathway involving FGF8/Snai1 controls asymmetric development of the proepicardium in the chick embryo. Proc. Natl. Acad. Sci. SUA 2009, 106, 7485-7490. [CrossRef]

288. Torlopp, A.; Schlueter, J.; Brand, T. Role of fibroblast growth factor signaling during proepicardium formation in the chick embryo. Dev. Dyn. 2010, 239, 2393-2403. [CrossRef]

289. Li, J.; Miao, L.; Zhao, C.; Shaikh, Q.W.M.; Shieh, D.; Guo, H.; Lu, Y.; Hu, S.; Huang, A.; Zhang, L.; et al. CDC42 is required for epicardial and pro-epicardial development by mediating FGF receptor trafficking to the plasma membrane. Development 2017, 144, 1635-1647. [CrossRef]

290. Kruithof, B.P.; Van Wijk, B.; Somi, S.; Kruithof-de Julio, M.; Pérez Pomares, J.M.; Weesie, F.; Wessels, A.; Moorman, A.F.; van der Hoff, M.J. BMP and FGF regulate the differentiation of multipotential pericardial mesoderm into the myocardial or epicardial lineage. Dev. Biol. 2006, 295, 507-522. [CrossRef]

291. Dueñas, A.; Aranega, A.E.; Franco, D. More than Just a Simple Cardiac Envelope; Cellular Contributions of the Epicardium. Front. Cell Dev. Biol. 2017, 5, 44. [CrossRef]

292. Carmona, R.; Guadix, J.A.; Cano, E.; Ruiz-Villalba, A.; Portillo-Sánchez, V.; Pérez-Pomares, J.M.; Pérez-Pomares, R. The embryonic epicardium: An essential element of cardiac development. J. Cell Mol. Med. 2010, 14, 2066-2072. [CrossRef] [PubMed]

293. Peralta, M.; González-Rosa, J.M.; Marques, I.J.; Mercader, N. The Epicardium in the Embryonic and Adult Zebrafish. J. Dev. Biol. 2014, 2, 101-116. [CrossRef] [PubMed]

294. Männer, J.; Pérez-Pomares, J.; Macías, D.; Muñoz-Chápuli, R. The Origin, Formation and Developmental Significance of the Epicardium: A Review. Cells Tissues Organs 2001, 169, 89-103. [CrossRef] [PubMed]

295. Pérez-Pomares, J.M.; de la Pompa, J.L. Signaling during epicardium and coronary vessel development. Circ. Res. 2011, 109, 1429-1442. [CrossRef]

296. Olivey, H.E.; Compton, L.A.; Barnett, J.V. Coronary Vessel DevelopmentThe Epicardium Delivers. Trends Cardiovasc. Med. 2004, 14, 247-251. [CrossRef]

297. Cano, E.; Carmona, R.; Ruiz-Villalba, A.; Rojas, A.; Chau, Y.-Y.; Wagner, K.D.; Wagner, N.; Hastie, N.D.; Muñoz-Chápuli, R.; Pérez-Pomares, J.M. Extracardiac septum transversum/proepicardial endothelial cells pattern embryonic coronary arterio-venous connections. Proc. Natl. Acad. Sci. USA 2016, 113, 656-661. [CrossRef]

298. Carmona, R.; Barrena, S.; Gambero, A.J.L.; Rojas, A.; Muñoz-Chápuli, R. Epicardial cell lineages and the origin of the coronary endothelium. FASEB J. 2020, 34, 5223-5239. [CrossRef]

299. Zamora, M.; Männer, J.; Ruiz-Lozano, P. Epicardium-derived progenitor cells require beta-catenin for coronary artery formation. Proc. Natl. Acad. Sci. USA 2007, 104, 18109-18114. [CrossRef]

300. Smart, N.; Riley, P.R. The epicardium as a candidate for heart regeneration. Future Cardiol. 2012, 8, 53-69. [CrossRef]

301. Kathiriya, I.S.; Srivastava, D. Left-right asymmetry and cardiac looping: Implications for cardiac development and congenital heart disease. Am. J. Med. Genet. 2000, 97, 271-279. [CrossRef]

302. Anderson, R.H.; Brown, N.A.; Meno, C.; Spicer, D. The importance of being isomeric. Clin. Anat. 2015, 28, 477-486. [CrossRef]

303. Bartram, U.; Wirbelauer, J.; Speer, C.P. Heterotaxy Syndrome-Asplenia and Polysplenia as Indicators of Visceral Malposition and Complex Congenital Heart Disease. Biol. Neonate 2005, 88, 278-290. [CrossRef]

304. Belmont, J.W.; Mohapatra, B.; Towbin, J.A.; Ware, S.M. Molecular genetics of heterotaxy syndromes. Curr. Opin. Cardiol. 2004, 19, 216-220. [CrossRef]

305. Degenhardt, K.; Rychik, J. Fetal Situs, Isomerism, Heterotaxy Syndrome: Diagnostic Evaluation and Implication for Postnatal Management. Curr. Treat Options Cardiovasc. Med. 2016, 18, 77. [CrossRef]

306. Kothari, S.S. Non-cardiac issues in patients with heterotaxy syndrome. Ann. Pediatr. Cardiol. 2014, 7, 187-192. [CrossRef] 
307. Mishra, S. Cardiac and Non-Cardiac Abnormalities in Heterotaxy Syndrome. Indian J. Pediatr. 2015, 82, 1135-1146. [CrossRef] [PubMed]

308. Phoon, C.K.; Neill, C.A. Asplenia syndrome: Insight into embryology through an analysis of cardiac and extracardiac anomalies. Am. J. Cardiol. 1994, 73, 581-587. [CrossRef]

309. Sutherland, M.J.; Ware, S.M. Disorders of left-right asymmetry: Heterotaxy and situs inversus. Am. J. Med. Genet. Part C Semin. Med. Genet. 2009, 15, 307-317. [CrossRef]

310. Tawfik, A.; Batouty, N.M.; Zaky, M.M.; Eladalany, M.A.; Elmokadem, A.H. Polysplenia syndrome: A review of the relationship with viscero-atrial situs and the spectrum of extra-cardiac anomalies. Surg. Radiol. Anat. 2013, 35, 647-653. [CrossRef] [PubMed]

311. Rudat, C.; Kispert, A. Wt1 and Epicardial Fate Mapping. Circ. Res. 2012, 111, 165-169. [CrossRef]

312. Wu, S.-P.; Dong, X.-R.; Regan, J.N.; Su, C.; Majesky, M.W. Tbx18 regulates development of the epicardium and coronary vessels. Dev. Biol. 2013, 383, 307-320. [CrossRef]

313. Brønnum, H.; Andersen, D.C.; Schneider, M.; Sandberg, M.B.; Eskildsen, T.; Nielsen, S.B.; Kalluri, R.; Sheikh, S.P. miR-21 Promotes Fibrogenic Epithelial-to-Mesenchymal Transition of Epicardial Mesothelial Cells Involving Programmed Cell Death 4 and Sprouty-1. PLOS ONE 2013, 8, e56280. [CrossRef]

314. Brønnum, H.; Andersen, D.C.; Schneider, M.; Nossent, A.Y.; Nielsen, S.B.; Sheikh, S.P. Islet-1 is a dual regulator of fibrogenic epithelial-to-mesenchymal transition in epicardial mesothelial cells. Exp. Cell Res. 2013, 319, 424-435. [CrossRef] [PubMed]

315. Romano, N.; Ceci, M. Heart regeneration is regulates by key micro RNAs from fish to mammals: What it can learned about the epicardial cells activation during the regeneration in zebrafish. Cell Death Dis. 2018, 9, 650. [CrossRef] [PubMed]

316. Jankowska-Steifer, E.; Niderla-Bielińska, J.; Ciszek, B.; Kujawa, M.; Bartkowiak, M.; Flaht-Zabost, A.; Klosinska, D.; Ratajska, A. Cells with hematopoietic potential reside within mouse proepicardium. Histochem. Cell Biol. 2018, 149, 577-591. [CrossRef] [PubMed]

317. Cossette, S.; Misra, R.P.; Cossett, S. The identification of different endothelial cell populations within the mouse proepicardium. Dev. Dyn. 2011, 240, 2344-2353. [CrossRef] [PubMed]

318. Wilting, J.; Buttler, K.; Schulte, I.; Papoutsi, M.; Schweigerer, L.; Männer, J. The proepicardium delivers hemangioblasts but not lymphangioblasts to the developing heart. Dev. Biol. 2007, 305, 451-459. [CrossRef]

319. Niderla-Bielińska, J.; Gula, G.; Flaht-Zabost, A.; Jankowska-Steifer, E.; Czarnowska, E.; Radomska-Leśniewska, D.M.; Ciszek, B.; Ratajska, A. 3-D reconstruction and multiple marker analysis of mouse proepicardial endothelial cell population. Microvasc. Res. 2015, 102, 54-69. [CrossRef]

320. Singh, M.K.; Lu, M.M.; Massera, D.; Epstein, J.A. MicroRNA-processing enzyme Dicer is required in epicardium for coronary vasculature development. J. Biol. Chem. 2011, 286, 41036-41045. [CrossRef]

321. Dueñas, A.; Expósito, A.; Muñoz, M.D.M.; de Manuel, M.J.; Cámara-Morales, A.; Serrano-Osorio, F.; García-Padilla, C.; HernándezTorres, F.; Domínguez, J.N.; Aránega, A.; et al. MiR-195 enhances cardiomyogenic differentiation of the proepicardium/septum transversum by Smurf1 and Foxp1 modulation. Sci. Rep. 2020, 10, 9334. [CrossRef] [PubMed]

322. Takahashi, M.; Yamagishi, T.; Narematsu, M.; Kamimura, T.; Kai, M.; Nakajima, Y. Epicardium is required for sarcomeric maturation and cardiomyocyte growth in the ventricular compact layer mediated by transforming growth factor $\beta$ and fibroblast growth factor before the onset of coronary circulation. Congenit Anom. (Kyoto) 2014, 54, 162-171. [CrossRef]

323. Gittenberger-de Groot, A.C.; Winter, E.M.; Poelmann, R.E. Epicardium-derived cells (EPDCs) in development, cardiac disease and repair of ischemia. J. Cell Mol. Med. 2018, 14, 1056-1060. [CrossRef] [PubMed]

324. Tevosian, S.G.; E Deconinck, A.; Tanaka, M.; Schinke, M.; Litovsky, S.H.; Izumo, S.; Fujiwara, Y.; Orkin, S.H. FOG-2, a Cofactor for GATA Transcription Factors, Is Essential for Heart Morphogenesis and Development of Coronary Vessels from Epicardium. Cell 2000, 101, 729-739. [CrossRef]

325. Towbin, J.A.; Lorts, A.; Jefferies, J.L. Left ventricular non-compaction cardiomyopathy. Lancet 2015, 386, 813-825. [CrossRef]

326. Weisz, S.H.; Limongelli, G.; Pacileo, G.; Calabrò, P.; Russo, M.G.; Calabrò, R.; Vatta, M. Left Ventricular Non Compaction in Children. Congenit. Heart Dis. 2010, 5, 384-397. [CrossRef]

327. Ikeda, U.; Minamisawa, M.; Koyama, J. Isolated left ventricular non-compaction cardiomyopathy in adults. J. Cardiol. 2015, 65, 91-97. [CrossRef]

328. Pérez-Pomares, J.M.; De La Pompa, J.L.; Franco, D.; Henderson, D.; Ho, S.Y.; Houyel, L.; Kelly, R.G.; Sedmera, D.; Sheppard, M.; Sperling, S.; et al. Congenital coronary artery anomalies: A bridge from embryology to anatomy and pathophysiology-A position statement of the development, anatomy, and pathology ESC Working Group. Cardiovasc. Res. 2016, 109, $204-216$. [CrossRef]

329. Moorman, A.F.M.; Christoffels, V.M. Cardiac Chamber Formation: Development, Genes, and Evolution. Physiol. Rev. 2003, 83, 1223-1267. [CrossRef]

330. Van den Berg, G.; Abu-Issa, R.; de Boer, B.A.; Hutson, M.R.; de Boer, P.A.; Soufan, A.T.; Ruijter, J.M.; Kirby, M.L.; van den Hoff, M.J.; Moorman, A.F. A caudal proliferating growth center contributes to both poles of the forming heart tube. Circ. Res. 2009, 104, 179-188. [CrossRef]

331. Sedmera, D.; Reckova, M.; DeAlmeida, A.; Coppen, S.R.; Kubalak, S.W.; Gourdie, R.G.; Thompson, R.P. Spatiotemporal pattern of commitment to slowed proliferation in the embryonic mouse heart indicates progressive differentiation of the cardiac conduction system. Anat. Rec. A Discov. Mol. Cell Evol. Biol. 2003, 274, 773-777. [CrossRef] 
332. Jensen, B.; Wang, T.; Christoffels, V.M.; Moorman, A.F.M. Evolution and development of the building plan of the vertebrate heart. Biochim. Biophys. Acta (BBA)-Bioenerg. 2013, 1833, 783-794. [CrossRef]

333. Moorman, A.F.M.; Soufan, A.T.; Hagoort, J.; Boer, P.A.J.; Christoffels, V.M. Development of the Building Plan of the Heart. Ann. N. Y. Acad. Sci. 2004, 1015, 171-181. [CrossRef] [PubMed]

334. Chinchilla, A.; Lozano, E.; Daimi, H.; Esteban, F.J.; Crist, C.; Aranega, A.E.; Franco, D. MicroRNA profiling during mouse ventricular maturation: A role for miR-27 modulating Mef2c expression. Cardiovasc. Res. 2010, 89, 98-108. [CrossRef]

335. Bonet, F.; Hernández-Torres, F.; Esteban, F.J.; Aranega, A.; Franco, D. Comparative Analyses of MicroRNA Microarrays during Cardiogenesis: Functional Perspectives. Microarrays 2013, 2, 81-96. [CrossRef]

336. Qin, X.; Gao, S.; Yang, Y.; Wu, L.; Wang, L. microRNA-25 promotes cardiomyocytes proliferation and migration via targeting Bim J. Cell. Physiol. 2019, 234, 22103-22115. [CrossRef]

337. García-Padilla, C.; Domínguez, J.N.; Aránega, A.E.; Franco, D. Differential chamber-specific expression and regulation of long non-coding RNAs during cardiac development. Biochim. Biophys. Acta (BBA)-Bioenerg. 2019, 1862, 194435. [CrossRef]

338. Pozzo, E.; Chai, Y.C.; Sampaolesi, M. Comprehensive Overview of Non-coding RNAs in Cardiac Development. Adv. Exp. Med. Biol. 2020, 1229, 197-211. [CrossRef]

339. Deacon, D.C.; Nevis, K.R.; Cashman, T.J.; Zhou, Y.; Zhao, L.; Washko, D.; Guner-Ataman, B.; Burns, C.G.; Burns, C.G.; Burns, C.E. The miR-143-adducin3 pathway is essential for cardiac chamber morphogenesis. Development 2010, 137, 1887-1896. [CrossRef] [PubMed]

340. Morton, S.U.; Scherz, P.J.; Cordes, K.R.; Ivey, K.N.; Stainier, D.Y.R.; Srivastava, D. microRNA-138 modulates cardiac patterning during embryonic development. Proc. Natl. Acad. Sci. USA 2008, 105, 17830-17835. [CrossRef]

341. Mosimann, C.; Panáková, D.; Werdich, A.A.; Musso, G.; Burger, A.; Lawson, K.L.; Carr, L.A.; Nevis, K.R.; Sabeh, M.K.; Zhou, Y.; et al. Chamber identity programs drive early functional partitioning of the heart. Nat. Commun. 2015, 6, 8146. [CrossRef]

342. Niessen, K.; Karsan, A. Notch Signaling in Cardiac Development. Circ. Res. 2008, 102, 1169-1181. [CrossRef]

343. Grego-Bessa, J.; Luna-Zurita, L.; Del Monte, G.; Bolós, V.; Melgar, P.; Arandilla, A.; Garratt, A.N.; Zang, H.; Mukouyama, Y.-S.; Chen, H.; et al. Notch Signaling Is Essential for Ventricular Chamber Development. Dev. Cell 2007, 12, 415-429. [CrossRef]

344. Samsa, L.A.; Givens, C.; Tzima, E.; Stainier, D.Y.R.; Qian, L.; Liu, J. Cardiac contraction activates endocardial Notch signaling to modulate chamber maturation in zebrafish. Development 2015, 142, 4080-4091. [CrossRef]

345. Del Monte-Nieto, G.; Ramialison, M.; Adam, A.A.S.; Wu, B.; Aharonov, A.; D’Uva, G.; Bourke, L.M.; Pitulescu, M.E.; Chen, H.; de la Pompa, J.L.; et al. Control of cardiac jelly dynamics by NOTCH1 and NRG1 defines the building plan for trabeculation. Nature 2018, 557, 439-445. [CrossRef] [PubMed]

346. Peshkovsky, C.; Totong, R.; Yelon, D. Dependence of cardiac trabeculation on neuregulin signaling and blood flow in zebrafish. Dev. Dyn. 2011, 240, 446-456. [CrossRef]

347. Lai, D.; Liu, X.; Forrai, A.; Wolstein, O.; Michalicek, J.; Ahmed, I.; Garratt, A.N.; Birchmeier, C.; Zhou, M.; Hartley, L.; et al. Neuregulin 1 Sustains the Gene Regulatory Network in Both Trabecular and Nontrabecular Myocardium. Circ. Res. 2010, 107, 715-727. [CrossRef] [PubMed]

348. Yang, Y.; Li, B.; Zhang, X.; Zhao, Q.; Lou, X. The zinc finger protein Zfpm1 modulates ventricular trabeculation through Neuregulin-ErbB signalling. Dev. Biol. 2019, 446, 142-150. [CrossRef] [PubMed]

349. Rasouli, S.J.; Stainier, D.Y. Regulation of cardiomyocyte behavior in zebrafish trabeculation by Neuregulin 2a signaling. Nat. Commun. 2017, 8, 15281. [CrossRef]

350. Negro, A.; Brar, B.K.; Lee, K.-F. Essential roles of Her2/erbB2 in cardiac development and function. Recent Prog. Horm. Res. 2004, 59, 1-12. [CrossRef]

351. van Weerd, J.H.; Christoffels, V.M. The formation and function of the cardiac conduction system. Development 2016, 143, 197-210. [CrossRef] [PubMed]

352. Mohan, R.A.; Boukens, B.J.; Christoffels, V.M. Developmental Origin of the Cardiac Conduction System: Insight from Lineage Tracing. Pediatr. Cardiol. 2018, 39, 1107-1114. [CrossRef] [PubMed]

353. van Eif, V.W.W.; Devalla, H.D.; Boink, G.J.J.; Christoffels, V.M. Transcriptional regulation of the cardiac conduction system. Nat. Rev. Cardiol. 2018, 15, 617-630. [CrossRef]

354. van Eif, V.W.W.; Stefanovic, S.; Mohan, R.A.; Christoffels, V.M. Gradual differentiation and confinement of the cardiac conduction system as indicated by marker gene expression. Biochim. Biophys. Acta Mol. Cell Res. 2020, 1867, 118509. [CrossRef]

355. Jensen, B.; Boukens, B.J.; Crossley, D.A.; Conner, J.; Mohan, R.A.; van Duijvenboden, K.; Postma, A.V.; Gloschat, C.R.; Elsey, R.M.; Sedmera, D.; et al. Specialized impulse conduction pathway in the alligator heart. eLife 2018, 7, e32120. [CrossRef] [PubMed]

356. Jensen, B.; Boukens, B.J.D.; Postma, A.V.; Gunst, Q.D.; van den Hoff, M.J.; Moorman, A.F.M.; Wang, T.; Christoffels, V.M. Identifying the Evolutionary Building Blocks of the Cardiac Conduction System. PLoS ONE 2012, 7, e44231. [CrossRef]

357. Christoffels, V.M.; Smits, G.J.; Kispert, A.; Moorman, A.F.M. Development of the Pacemaker Tissues of the Heart. Circ. Res. 2010, 106, 240-254. [CrossRef]

358. Bakker, M.L.; Moorman, A.F.M.; Christoffels, V.M. The Atrioventricular Node: Origin, Development, and Genetic Program. Trends Cardiovasc. Med. 2010, 20, 164-171. [CrossRef]

359. Bakker, M.L.; Christoffels, V.M.; Moorman, A.F.M. The Cardiac Pacemaker and Conduction System Develops From Embryonic Myocardium that Retains Its Primitive Phenotype. J. Cardiovasc. Pharmacol. 2010, 56, 6-15. [CrossRef] 
360. Tessadori, F.; Van Weerd, J.H.; Burkhard, S.B.; Verkerk, A.O.; De Pater, E.; Boukens, B.J.; Vink, A.; Christoffels, V.M.; Bakkers, J. Identification and Functional Characterization of Cardiac Pacemaker Cells in Zebrafish. PLoS ONE 2012, 7, e47644. [CrossRef]

361. Kvasilova, A.; Olejnickova, V.; Jensen, B.; Christoffels, V.M.; Kolesova, H.; Sedmera, D.; Gregorovicova, M. The formation of the atrioventricular conduction axis is linked in development to ventricular septation. J. Exp. Biol. 2020, 223, jeb229278. [CrossRef]

362. Aanhaanen, W.T.J.; Mommersteeg, M.T.M.; Norden, J.; Wakker, V.; Vries, C.D.G.-D.; Anderson, R.H.; Kispert, A.; Moorman, A.F.M.; Christoffels, V.M. Developmental Origin, Growth, and Three-Dimensional Architecture of the Atrioventricular Conduction Axis of the Mouse Heart. Circ. Res. 2010, 107, 728-736. [CrossRef] [PubMed]

363. Vicente-Steijn, R.; Kelder, T.P.; Tertoolen, L.G.; Wisse, L.J.; Pijnappels, D.A.; Poelmann, R.; Schalij, M.J.; DeRuiter, M.C.; Groot, A.C.G.-D.; Jongbloed, M. RHOA-ROCK signalling is necessary for lateralization and differentiation of the developing sinoatrial node. Cardiovasc. Res. 2017, 113, 1186-1197. [CrossRef] [PubMed]

364. Gourdie, R.G.; Mima, T.; Thompson, R.P.; Mikawa, T. Terminal diversification of the myocyte lineage generates Purkinje fibers of the cardiac conduction system. Development 1995, 121, 1423-1431.

365. Gourdie, R.G.; Wei, Y.; Kim, D.; Klatt, S.C.; Mikawa, T. Endothelin-induced conversion of embryonic heart muscle cells into impulse-conducting Purkinje fibers. Proc. Natl. Acad. Sci. USA 1998, 95, 6815-6818. [CrossRef] [PubMed]

366. Gourdie, R.G.; Harris, B.S.; Bond, J.; Edmondson, A.M.; Cheng, G.; Sedmera, D.; O’Brien, T.X.; Mikawa, T.; Thompson, R.P. His-Purkinje lineages and development. Novartis Found. Symp. 2003, 250, 110-124. [CrossRef]

367. Gourdie, R.G.; Harris, B.S.; Bond, J.; Justus, C.; Hewett, K.W.; O’Brien, T.X.; Thompson, R.P.; Sedmera, D. Development of the cardiac pacemaking and conduction system. Birth Defects Res. C Embryo Today 2003, 69, 46-57. [CrossRef]

368. Cheng, G.; Litchenberg, W.H.; Cole, G.J.; Mikawa, T.; Thompson, R.P.; Gourdie, R.G. Development of the cardiac conduction system involves recruitment within a multipotent cardiomyogenic lineage. Development 1999, 126, 5041-5049.

369. Sedmera, D.; Harris, B.S.; Grant, E.; Zhang, N.; Jourdan, J.; Kurková, D.; Gourdie, R.G. Cardiac expression patterns of endothelinconverting enzyme (ECE): Implications for conduction system development. Dev. Dyn. 2008, 237, 1746-1753. [CrossRef]

370. Takebayashi-Suzuki, K.; Yanagisawa, M.; Gourdie, R.G.; Kanzawa, N.; Mikawa, T. In vivo induction of cardiac Purkinje fiber differentiation by coexpression of preproendothelin-1 and endothelin converting enzyme-1. Development 2000, 127, $3523-3532$.

371. Hyer, J.; Johansen, M.; Prasad, A.; Wessels, A.; Kirby, M.L.; Gourdie, R.G.; Mikawa, T. Induction of Purkinje fiber differentiation by coronary arterialization. Proc. Natl. Acad. Sci. USA 1999, 96, 13214-13218. [CrossRef] [PubMed]

372. Miquerol, L.; Moreno-Rascon, N.; Beyer, S.; Dupays, L.; Meilhac, S.M.; Buckingham, M.E.; Franco, D.; Kelly, R.G. Biphasic Development of the Mammalian Ventricular Conduction System. Circ. Res. 2010, 107, 153-161. [CrossRef] [PubMed]

373. Miquerol, L.; Beyer, S.; Kelly, R.G. Establishment of the mouse ventricular conduction system. Cardiovasc. Res. 2011, 91, 232-242. [CrossRef]

374. Miquerol, L.; Bellon, A.; Moreno, N.; Beyer, S.; Meilhac, S.M.; Buckingham, M.; Franco, D.; Kelly, R.G. Resolving cell lineage contributions to the ventricular conduction system with a Cx40-GFP allele: A dual contribution of the first and second heart fields. Dev. Dyn. 2013, 242, 665-677. [CrossRef]

375. Choquet, C.; Kelly, R.G.; Miquerol, L. Defects in Trabecular Development Contribute to Left Ventricular Noncompaction. Pediatr. Cardiol. 2019, 40, 1331-1338. [CrossRef] [PubMed]

376. Choquet, C.; Marcadet, L.; Beyer, S.; Kelly, R.G.; Miquerol, L. Segregation of Central Ventricular Conduction System Lineages in Early SMA+ Cardiomyocytes Occurs Prior to Heart Tube Formation. J. Cardiovasc. Dev. Dis. 2016, 3, 2. [CrossRef]

377. Choquet, C.; Nguyen, T.H.M.; Sicard, P.; Buttigieg, E.; Tran, T.T.; Kober, F.; Varlet, I.; Sturny, R.; Costa, M.W.; Harvey, R.P.; et al. Deletion of Nkx2-5 in trabecular myocardium reveals the developmental origins of pathological heterogeneity associated with ventricular non-compaction cardiomyopathy. PLoS Genet. 2018, 14, e1007502.

378. Bakker, M.L.; Boukens, B.J.; Mommersteeg, M.T.M.; Brons, J.F.; Wakker, V.; Moorman, A.F.M.; Christoffels, V.M. Transcription Factor Tbx3 Is Required for the Specification of the Atrioventricular Conduction System. Circ. Res. 2008, 102, 1340-1349. [CrossRef]

379. Wang, J.; Bai, Y.; Li, N.; Ye, W.; Zhang, M.; Greene, S.B.; Tao, Y.; Chen, Y.; Wehrens, X.H.T.; Martin, J.F. Pitx2-microRNA pathway that delimits sinoatrial node development and inhibits predisposition to atrial fibrillation. Proc. Natl. Acad. Sci. USA 2014, 111, 9181-9186. [CrossRef]

380. Bond, J.; Sedmera, D.; Jourdan, J.; Zhang, Y.; Eisenberg, C.A.; Eisenberg, L.M.; Gourdie, R.G. Wnt11 and Wnt7a are up-regulated in association with differentiation of cardiac conduction cells in vitro and in vivo. Dev. Dyn. 2003, 227, 536-543. [CrossRef]

381. Samal, E.; Evangelista, M.; Galang, G.; Srivastava, D.; Zhao, Y.; Vedantham, V. Premature MicroRNA-1 Expression Causes Hypoplasia of the Cardiac Ventricular Conduction System. Front. Physiol. 2019, 10, 235. [CrossRef]

382. Zhao, Y.; Ransom, J.F.; Li, A.; Vedantham, V.; Von Drehle, M.; Muth, A.N.; Tsuchihashi, T.; McManus, M.T.; Schwartz, R.J.; Srivastava, D. Dysregulation of Cardiogenesis, Cardiac Conduction, and Cell Cycle in Mice Lacking miRNA-1-2. Cell 2007, 129, 303-317. [CrossRef]

383. Garnatz, A.S.; Gao, Z.; Broman, M.; Martens, S.; Earley, J.U.; Svensson, E.C. FOG-2 mediated recruitment of the NuRD complex regulates cardiomyocyte proliferation during heart development. Dev. Biol. 2014, 395, 50-61. [CrossRef]

384. Shamis, Y.; Cullen, D.E.; Liu, L.; Yang, G.; Ng, S.F.; Xiao, L.; Bell, F.T.; Ray, C.; Takikawa, S.; Moskowitz, I.P.; et al. Maternal and zygotic Zfp57 modulate NOTCH signaling in cardiac development. Proc. Natl. Acad. Sci. USA 2015, 112, E2020-E2029. [CrossRef]

385. Chen, X.; Qin, L.; Liu, Z.; Liao, L.; Martin, J.F.; Xu, J. Knockout of SRC-1 and SRC-3 in Mice Decreases Cardiomyocyte Proliferation and Causes a Noncompaction Cardiomyopathy Phenotype. Int. J. Biol. Sci. 2015, 11, 1056-1072. [CrossRef] 
386. Harmelink, C.; Peng, Y.; DeBenedittis, P.; Chen, H.; Shou, W.; Jiao, K. Myocardial Mycn is essential for mouse ventricular wall morphogenesis. Dev. Biol. 2013, 373, 53-63. [CrossRef]

387. Xiuzhen, H.; Tian, X.; Zhang, H.; Hu, T.; Huang, X.; Zhang, L.; Wang, Z.; Zhou, B. BAF200 Is Required for Heart Morphogenesis and Coronary Artery Development. PLoS ONE 2014, 9, e109493. [CrossRef]

388. Yagi, H.; Liu, X.; Gabriel, G.C.; Wu, Y.; Peterson, K.; Murray, S.A.; Aronow, B.J.; Martin, L.J.; Benson, D.W.; Lo, C.W. The Genetic Landscape of Hypoplastic Left Heart Syndrome. Pediatr. Cardiol. 2018, 39, 1069-1081. [CrossRef] [PubMed]

389. Liu, X.; Yagi, H.; Saeed, S.; Bais, A.S.; Gabriel, G.C.; Chen, Z.; A Peterson, K.; Li, Y.; Schwartz, M.C.; Reynolds, W.T.; et al. The complex genetics of hypoplastic left heart syndrome. Nat. Genet. 2017, 49, 1152-1159. [CrossRef] [PubMed]

390. Bruneau, B.G.; Bao, Z.-Z.; Fatkin, D.; Xavier-Neto, J.; Georgakopoulos, D.; Maguire, C.T.; Berul, C.I.; Kass, D.A.; Bold, M.L.K.-D.; De Bold, A.J.; et al. Cardiomyopathy in Irx4-Deficient Mice Is Preceded by Abnormal Ventricular Gene Expression. Mol. Cell. Biol. 2001, 21, 1730-1736. [CrossRef] [PubMed]

391. Tomita-Mitchell, A.; Stamm, K.D.; Mahnke, D.K.; Kim, M.-S.; Hidestrand, P.M.; Liang, H.L.; Goetsch, M.A.; Hidestrand, M.; Simpson, P.; Pelech, A.N.; et al. Impact of MYH6 variants in hypoplastic left heart syndrome. Physiol. Genom. 2016, 48, 912-921. [CrossRef]

392. Durbin, M.D.; Cadar, A.G.; Williams, C.H.; Guo, Y.; Bichell, D.P.; Su, Y.R.; Hong, C.C. Hypoplastic Left Heart Syndrome Sequencing Reveals a Novel NOTCH1 Mutation in a Family with Single Ventricle Defects. Pediatr. Cardiol. 2017, 38, 1232-1240. [CrossRef] [PubMed]

393. Fitzgerald, K.K.; Bhat, A.M.; Conard, K.; Hyland, J.; Pizarro, C. Novel SMAD3 Mutation in a Patient with Hypoplastic Left Heart Syndrome with Significant Aortic Aneurysm. Case Rep. Genet. 2014, 2014, 591516. [CrossRef] [PubMed]

394. Verhagen, J.M.; Born, M.V.D.; Kurul, S.; Asimaki, A.; Van De Laar, I.M.B.H.; Frohn-Mulder, I.M.; Kammeraad, J.A.; Yap, S.C.; Bartelings, M.M.; Van Slegtenhorst, M.A.; et al. Homozygous Truncating Variant in PKP2 Causes Hypoplastic Left Heart Syndrome. Circ. Genom. Precis. Med. 2018, 11, e002397. [CrossRef]

395. Dueñas, A.; Expósito-Villén, A.; Aranega, A.; Franco, D. The Role of Non-Coding RNA in Congenital Heart Diseases. J. Cardiovasc. Dev. Dis. 2019, 6, 15. [CrossRef]

396. Liang, D.; Xu, X.; Deng, F.; Feng, J.; Zhang, H.; Liu, Y.; Zhang, Y.; Pan, L.; Liu, Y.; Zhang, D.; et al. miRNA-940 reduction contributes to human Tetralogy of Fallot development. J. Cell Mol. Med. 2014, 18, 1830-1839. [CrossRef]

397. Saxena, A.; Tabin, C.J. miRNA-processing enzyme Dicer is necessary for cardiac outflow tract alignment and chamber septation. Proc. Natl. Acad. Sci. USA. 2010, 107, 87-91. [CrossRef]

398. Xu, J.; Hu, Z.; Xu, Z.; Gu, H.; Yi, L.; Cao, H.; Chen, J.; Tian, T.; Liang, J.; Lin, Y.; et al. Functional variant in microRNA-196a2 contributes to the susceptibility of congenital heart disease in a Chinese population. Hum. Mutat. 2009, 30, 1231-1236. [CrossRef] [PubMed]

399. Kobayashi, J.; Yoshida, M.; Tarui, S.; Hirata, M.; Nagai, Y.; Kasahara, S.; Naruse, K.; Ito, H.; Sano, S.; Oh, H. Directed Differentiation of Patient-Specific Induced Pluripotent Stem Cells Identifies the Transcriptional Repression and Epigenetic Modification of NKX2-5, HAND1, and NOTCH1 in Hypoplastic Left Heart Syndrome. PLoS ONE 2014, 9, e102796. [CrossRef] [PubMed]

400. Aanhaanen, W.T.; Boukens, B.J.; Sizarov, A.; Wakker, V.; Vries, C.D.G.-D.; Van Ginneken, A.C.; Moorman, A.F.; Coronel, R.; Christoffels, V.M. Defective Tbx2-dependent patterning of the atrioventricular canal myocardium causes accessory pathway formation in mice. J. Clin. Investig. 2011, 121, 534-544. [CrossRef]

401. Frank, D.U.; Carter, K.L.; Thomas, K.R.; Burr, R.M.; Bakker, M.L.; Coetzee, W.A.; Tristani-Firouzi, M.; Bamshad, M.J.; Christoffels, V.M.; Moon, A.M. Lethal arrhythmias in Tbx3-deficient mice reveal extreme dosage sensitivity of cardiac conduction system function and homeostasis. Proc. Natl. Acad. Sci. USA 2011, 109, E154-E163. [CrossRef] [PubMed]

402. Theis, J.L.; Zimmermann, M.T.; Evans, J.M.; Eckloff, B.W.; Wieben, E.D.; Qureshi, M.Y.; O'Leary, P.W.; Olson, T.M. Recessive MYH6 Mutations in Hypoplastic Left Heart With Reduced Ejection Fraction. Circ. Cardiovasc. Genet. 2015, 8, 564-571. [CrossRef]

403. Theis, J.L.; Hrstka, S.C.L.; Evans, J.M.; O’Byrne, M.M.; De Andrade, M.; O’Leary, P.W.; Nelson, T.J.; Olson, T.M. Compound heterozygous NOTCH1 mutations underlie impaired cardiogenesis in a patient with hypoplastic left heart syndrome. Qual. Life Res. 2015, 134, 1003-1011. [CrossRef]

404. Cao, Y.; Wang, J.; Wei, C.; Hou, Z.; Li, Y.; Zou, H.; Meng, M.; Wang, W.; Jiang, L. Genetic variations of NKX2-5 in sporadic atrial septal defect and ventricular septal defect in Chinese Yunnan population. Gene 2016, 575, 29-33. [CrossRef]

405. Hirayama-Yamada, K.; Kamisago, M.; Akimoto, K.; Aotsuka, H.; Nakamura, Y.; Tomita, H.; Furutani, M.; Imamura, S.-I.; Takao, A.; Nakazawa, M.; et al. Phenotypes withGATA4 orNKX2.5 mutations in familial atrial septal defect. Am. J. Med. Genet. Part A 2005, 135, 47-52. [CrossRef]

406. Mohan, R.A.; Van Engelen, K.; Stefanovic, S.; Barnett, P.; Ilgun, A.; Baars, M.J.H.; Bouma, B.J.; Mulder, B.J.M.; Christoffels, V.M.; Postma, A.V. A mutation in the Kozak sequence ofGATA4hampers translation in a family with atrial septal defects. Am. J. Med. Genet. Part A 2014, 164, 2732-2738. [CrossRef]

407. Xu, Y.-J.; Qiu, X.-B.; Yuan, F.; Shi, H.-Y.; Xu, L.; Hou, X.-M.; Qu, X.-K.; Liu, X.; Huang, R.-T.; Xue, S.; et al. Prevalence and spectrum of NKX2.5 mutations in patients with congenital atrial septal defect and atrioventricular block. Mol. Med. Rep. 2017, 15, 2247-2254. [CrossRef]

408. Chen, J.; Qi, B.; Zhao, J.; Liu, W.; Duan, R.; Zhang, M. A novel mutation of GATA4 (K300T) associated with familial atrial septal defect. Gene 2016, 575, 473-477. [CrossRef] [PubMed] 
409. Xiang, R.; Fanm, L.L.; Huang, H.; Cao, B.B.; Li, X.P.; Peng, D.Q.; Xia, K. A novel mutation of GATA4 (K319E) is responsible for familial atrial septal defect and pulmonary valve stenosis. Gene 2014, 534, 320-323. [CrossRef]

410. Zhou, Y.; Dai, X.; Huang, R.-T.; Xue, S.; Xu, Y.-J.; Qiu, X.-B.; Yang, Y.-Q. A novel TBX20 loss-of-function mutation contributes to adult-onset dilated cardiomyopathy or congenital atrial septal defect. Mol. Med. Rep. 2016, 14, 3307-3314. [CrossRef] [PubMed]

411. Sun, Y.-M.; Wang, J.; Qiu, X.-B.; Yuan, F.; Li, R.-G.; Xu, Y.-J.; Qu, X.-K.; Shi, H.-Y.; Hou, X.-M.; Huang, R.-T.; et al. A HAND2 Loss-of-Function Mutation Causes Familial Ventricular Septal Defect and Pulmonary Stenosis. G3 (Bethesda) 2016, 6, 987-992. [CrossRef]

412. Wang, J.; Mao, J.-H.; Ding, K.-K.; Xu, W.-J.; Liu, X.-Y.; Qiu, X.-B.; Li, R.-G.; Qu, X.-K.; Xu, Y.-J.; Huang, R.-T.; et al. A Novel NKX2.6 Mutation Associated with Congenital Ventricular Septal Defect. Pediatr. Cardiol. 2014, 36, 646-656. [CrossRef]

413. Winston, J.B.; Schulkey, C.E.; Chen, I.-B.D.; Regmi, S.D.; Efimova, M.; Erlich, J.M.; Green, C.A.; Aluko, A.; Jay, P.Y. Complex Trait Analysis of Ventricular Septal Defects Caused by Nkx2-5 Mutation. Circ. Cardiovasc. Genet. 2012, 5, 293-300. [CrossRef]

414. Wei, W.; Li, B.; Li, F.; Sun, K.; Jiang, X.; Xu, R. Identification of FOXH1 mutations in patients with sporadic conotruncal heart defect. Clin. Genet. 2020, 97, 576-585. [CrossRef]

415. Zhao, C.-M.; Peng, L.-Y.; Li, L.; Liu, X.-Y.; Wang, J.; Zhang, X.-L.; Yuan, F.; Li, R.-G.; Qiu, X.-B.; Yang, Y.-Q. PITX2 Loss-of-Function Mutation Contributes to Congenital Endocardial Cushion Defect and Axenfeld-Rieger Syndrome. PLoS ONE 2015, 10, e0124409. [CrossRef]

416. Zhang, E.; Yang, J.; Liu, Y.; Hong, N.; Xie, H.; Fu, Q.; Li, F.; Chen, S.; Yu, Y.; Sun, K. MESP2 variants contribute to conotruncal heart defects by inhibiting cardiac neural crest cell proliferation. J. Mol. Med. 2020, 98, 1035-1048. [CrossRef]

417. Zhang, M.; Li, F.X.; Liu, X.Y.; Huang, R.T.; Xue, S.; Yang, X.X.; Li, Y.J.; Liu, H.; Shi, H.Y.; Pan, X.; et al. MESP1 loss-of-function mutation contributes to double outlet right ventricle. Mol. Med. Rep. 2017, 16, 2747-2754. [CrossRef]

418. Lin, X.; Huo, Z.; Liu, X.; Zhang, Y.; Li, L.; Zhao, H.; Yan, B.; Liu, Y.; Yang, Y.; Chen, Y.-H. A novel GATA6 mutation in patients with tetralogy of Fallot or atrial septal defect. J. Hum. Genet. 2010, 55, 662-667. [CrossRef]

419. Lu, C.-X.; Gong, H.-R.; Liu, X.; Wang, J.; Zhao, C.-M.; Huang, R.-T.; Xue, S.; Yang, Y.-Q. A novel HAND2 loss-of-function mutation responsible for tetralogy of Fallot. Int. J. Mol. Med. 2016, 37, 445-451. [CrossRef]

420. Li, R.-G.; Li, L.; Qiu, X.; Yuan, F.; Xu, L.; Li, X.; Xu, Y.; Jiang, W.-F.; Jiang, J.-Q.; Liu, X.; et al. GATA4 loss-of-function mutation underlies familial dilated cardiomyopathy. Biochem. Biophys. Res. Commun. 2013, 439, 591-596. [CrossRef]

421. Li, J.; Liu, W.-D.; Yang, Z.-L.; Yuan, F.; Xu, L.; Li, R.-G.; Yang, Y.-Q. Prevalence and spectrum of GATA4 mutations associated with sporadic dilated cardiomyopathy. Gene 2014, 548, 174-181. [CrossRef]

422. Zhao, L.; Xu, J.-H.; Xu, W.-J.; Yu, H.; Wang, Q.; Zheng, H.-Z.; Jiang, W.-F.; Jiang, J.-F.; Yang, Y.-Q. A novel GATA4 loss-of-function mutation responsible for familial dilated cardiomyopathy. Int. J. Mol. Med. 2013, 33, 654-660. [CrossRef] [PubMed]

423. Zhang, X.-L.; Qiu, X.-B.; Yuan, F.; Wang, J.; Zhao, C.-M.; Li, R.-G.; Xu, L.; Xu, Y.-J.; Shi, H.; Hou, X.-M.; et al. TBX5 loss-of-function mutation contributes to familial dilated cardiomyopathy. Biochem. Biophys. Res. Commun. 2015, 459, 166-171. [CrossRef]

424. Zhou, W.; Zhao, L.; Jiang, J.-Q.; Jiang, W.-F.; Yang, Y.-Q.; Qiu, X.-B. A novel TBX5 loss-of-function mutation associated with sporadic dilated cardiomyopathy. Int. J. Mol. Med. 2015, 36, 282-288. [CrossRef]

425. Xu, J.-H.; Gu, J.-Y.; Guo, Y.-H.; Zhang, H.; Qiu, X.-B.; Li, R.-G.; Shi, H.-Y.; Liu, H.; Yang, X.-X.; Xu, Y.-J.; et al. Prevalence and Spectrum of NKX2-5 Mutations Associated With Sporadic Adult-Onset Dilated Cardiomyopathy. Int. Heart J. 2017, 58, 521-529. [CrossRef] [PubMed]

426. Yuan, F.; Qiu, Z.-H.; Wang, X.-H.; Sun, Y.-M.; Wang, J.; Li, R.-G.; Liu, H.; Zhang, M.; Shi, H.-Y.; Zhao, L.; et al. MEF2C lossof-function mutation associated with familial dilated cardiomyopathy. Clin. Chem. Lab. Med. 2017, 56, 502-511. [CrossRef] [PubMed]

427. Li, R.-G.; Xu, Y.; Wang, J.; Liu, X.; Yuan, F.; Huang, R.-T.; Xue, S.; Li, L.; Liu, H.; Li, Y.-J.; et al. GATA4 Loss-of-Function Mutation and the Congenitally Bicuspid Aortic Valve. Am. J. Cardiol. 2018, 121, 469-474. [CrossRef]

428. Qu, X.-K.; Qiu, X.-B.; Yuan, F.; Wang, J.; Zhao, C.-M.; Liu, X.-Y.; Zhang, X.-L.; Li, R.-G.; Xu, Y.-J.; Hou, X.-M.; et al. A Novel NKX2.5 Loss-of-Function Mutation Associated With Congenital Bicuspid Aortic Valve. Am. J. Cardiol. 2014, 114, 1891-1895. [CrossRef]

429. Posch, M.G.; Boldt, L.-H.; Polotzki, M.; Richter, S.; Rolf, S.; Perrot, A.; Dietz, R.; Özcelik, C.; Haverkamp, W. Mutations in the cardiac transcription factor GATA4 in patients with lone atrial fibrillation. Eur. J. Med. Genet. 2010, 53, 201-203. [CrossRef]

430. Yuan, F.; Qiu, X.-B.; Li, R.-G.; Qu, X.-K.; Wang, J.; Xu, Y.-J.; Liu, X.; Fang, W.-Y.; Yang, Y.-Q.; Liao, D.-N. A novel NKX2-5 loss-of-function mutation predisposes to familial dilated cardiomyopathy and arrhythmias. Int. J. Mol. Med. 2014, 35, 478-486. [CrossRef]

431. Ma, J.-F.; Yang, F.; Mahida, S.N.; Zhao, L.; Chen, X.; Zhang, M.L.; Sun, Z.; Yao, Y.; Zhang, Y.-X.; Zheng, G.-Y.; et al. TBX5 mutations contribute to early-onset atrial fibrillation in Chinese and Caucasians. Cardiovasc. Res. 2016, 109, 442-450. [CrossRef]

432. Yang, F.; Zhou, L.; Wang, Q.; You, X.; Li, Y.; Zhao, Y.; Han, X.; Chang, Z.; He, X.; Cheng, C.; et al. NEXN inhibits GATA4 and leads to atrial septal defects in mice and humans. Cardiovasc. Res. 2014, 103, 228-237. [CrossRef]

433. Rivera-Feliciano, J.; Lee, K.-H.; Kong, S.W.; Rajagopal, S.; Ma, Q.; Springer, Z.; Izumo, S.; Tabin, C.J.; Pu, W.T. Development of heart valves requires Gata4 expression in endothelial-derived cells. Development 2006, 133, 3607-3618. [CrossRef]

434. de Vlaming, A.; Sauls, K.; Hajdu, Z.; Visconti, R.P.; Mehesz, A.N.; Levine, R.A.; Slaugenhaupt, S.A.; Hagège, A.; Chester, A.H.; Markwald, R.R.; et al. Atrioventricular valve development: New perspectives on an old theme. Differentiation 2012, 84, 103-116. [CrossRef] 
435. Stefanovic, S.; Barnett, P.; Van Duijvenboden, K.; Weber, D.; Gessler, M.; Christoffels, V.M. GATA-dependent regulatory switches establish atrioventricular canal specificity during heart development. Nat. Commun. 2014, 5, 3680. [CrossRef]

436. Lockhart, M.M.; Wirrig, E.E.; Phelps, A.L.; Ghatnekar, A.V.; Barth, J.L.; Norris, R.A.; Wessels, A. Mef2c Regulates Transcription of the Extracellular Matrix Protein Cartilage Link Protein 1 in the Developing Murine Heart. PLoS ONE 2013, 8, e57073. [CrossRef]

437. Franco, D.; Meilhac, S.M.; Christoffels, V.M.; Kispert, A.; Buckingham, M.; Kelly, R.G. Left and right ventricular contributions to the formation of the interventricular septum in the mouse heart. Dev. Biol. 2006, 294, 366-375. [CrossRef]

438. Takeuchi, J.K.; Ohgi, M.; Koshiba-Takeuchi, K.; Shiratori, H.; Sakaki, I.; Ogura, T.; Saijoh, Y. Tbx5 specifies the left/right ventricles and ventricular septum position during cardiogenesis. Development 2003, 130, 5953-5964. [CrossRef]

439. Vanyai, H.K.; Thomas, T.; Voss, A.K. Mesodermal expression of Moz is necessary for cardiac septum development. Dev. Biol. 2015, 403, 22-29. [CrossRef]

440. Yuasa, S.; Onizuka, T.; Shimoji, K.; Ohno, Y.; Kageyama, T.; Yoon, S.H.; Egashira, T.; Seki, T.; Hashimoto, H.; Nishiyama, T.; et al. Zac1 Is an Essential Transcription Factor for Cardiac Morphogenesis. Circ. Res. 2010, 106, 1083-1091. [CrossRef]

441. Panzer, A.A.; Regmi, S.D.; Cormier, D.; Danzo, M.T.; Chen, I.-B.D.; Winston, J.B.; Hutchinson, A.K.; Salm, D.; Schulkey, C.E.; Cochran, R.S.; et al. Nkx2-5 and Sarcospan genetically interact in the development of the muscular ventricular septum of the heart. Sci. Rep. 2017, 7, 46438. [CrossRef]

442. Ya, J.; van den Hoff, M.J.; de Boer, P.A.; Tesink-Taekema, S.; Franco, D.; Moorman, A.F.; Lamers, W.H. Normal development of the outflow tract in the rat. Circ Res. 1998, 82, 464-472. [CrossRef] [PubMed]

443. Franco, D.; Markman, M.M.; Wagenaar, G.T.; Ya, J.; Lamers, W.H.; Moorman, A.F. Myosin light chain 2a and 2v identifies the embryonic outflow tract myocardium in the developing rodent heart. Anat. Rec. 1999, 254, 135-146. [CrossRef]

444. Miyagawa-Tomita, S.; Waldo, K.; Tomita, H.; Kirby, M.L. Temporospatial study of the migration and distribution of cardiac neural crest in quail-chick chimeras. Am. J. Anat. 1991, 192, 79-88. [CrossRef]

445. Kirby, M.L. Cellular and molecular contributions of the cardiac neural crest to cardiovascular development. Trends Cardiovasc. Med. 1993, 3, 18-23. [CrossRef]

446. Creazzo, T.L.; Godt, R.E.; Leatherbury, L.; Conway, S.J.; Kirby, M.L. Role of cardiac neural crest cells in cardiovascular development. Annu. Rev. Physiol. 1998, 60, 267-286. [CrossRef] [PubMed]

447. Kirby, M.L.; Turnage, K.L.; Hays, B.M. Characterization of conotruncal malformations following ablation of "cardiac" neural crest. Anat. Rec. 1985, 213, 87-93. [CrossRef]

448. Bookman, D.E.; Redmond, M.E.; Waldo, K.; Davis, H.; Kirby, M.L. Effect of neural crest ablation on development of the heart and arch arteries in the chick. Am. J. Anat. 1987, 180, 332-341. [CrossRef]

449. Yelbuz, T.M.; Waldo, K.L.; Kumiski, D.H.; Stadt, H.A.; Wolfe, R.R.; Leatherbury, L.; Kirby, M.L. Shortened outflow tract leads to altered cardiac looping after neural crest ablation. Circulation 2002, 106, 504-510. [CrossRef] [PubMed]

450. Waldo, K.; Miyagawa-Tomita, S.; Kumiski, D.; Kirby, M.L. Cardiac neural crest cells provide new insight into septation of the cardiac outflow tract: Aortic sac to ventricular septal closure. Dev. Biol. 1998, 196, 129-144. [CrossRef]

451. Kanne, J.P.; Godwin, J.D. Right aortic arch and its variants. J. Cardiovasc. Comput. Tomogr. 2010, 4, 293-300. [CrossRef] [PubMed]

452. Gobel, J.W.; Pierpont, M.E.M.; Moller, J.H.; Singh, A.; Edwards, J.E. Familial interruption of the aortic arch. Pediatr. Cardiol. 1993, 14, 110-115. [CrossRef] [PubMed]

453. Bockman, D.E.; Redmond, M.E.; Kirby, M.L. Alteration of early vascular development after ablation of cranial neural crest. Anat. Rec. Adv. Integr. Anat. Evol. Biol. 1989, 225, 209-217. [CrossRef]

454. Kurihara, Y.; Kurihara, H.; Oda, H.; Maemura, K.; Nagai, R.; Ishikawa, T.; Yazaki, Y. Aortic arch malformations and ventricular septal defect in mice deficient in endothelin-1. J. Clin. Investig. 1995, 96, 293-300. [CrossRef]

455. Yanagisawa, H.; Hammer, R.E.; Richardson, J.A.; Williams, S.C.; Clouthier, D.E.; Yanagisawa, M. Role of Endothelin-1/EndothelinA receptor-mediated signaling pathway in the aortic arch patterning in mice. J. Clin. Investig. 1998, 102, 22-33. [CrossRef]

456. Thomas, T.; Kurihara, H.; Yamagishi, H.; Kurihara, Y.; Yazaki, Y.; Olson, E.N.; Srivastava, D. A signaling cascade involving endothelin-1, dHAND and msx1 regulates development of neural-crest-derived branchial arch mesenchyme. Development 1998, 125, 3005-3014. [PubMed]

457. Sugrue, K.F.; Sarkar, A.A.; Leatherbury, L.; Zohn, I.E. The ubiquitin ligase HECTD1 promotes retinoic acid signaling required for development of the aortic arch. Dis. Model. Mech. 2019, 12, dmm036491. [CrossRef]

458. Niederreither, K.; Vermot, J.; Le Roux, I.; Schuhbaur, B.; Chambon, P.; Dollé, P. The regional pattern of retinoic acid synthesis by RALDH2 is essential for the development of posterior pharyngeal arches and the enteric nervous system. Development 2003, 130, 2525-2534. [CrossRef]

459. Colbert, M.C.; Kirby, M.L.; Robbins, J. Endogenous retinoic acid signaling colocalizes with advanced expression of the adult smooth muscle myosin heavy chain isoform during development of the ductus arteriosus. Circ. Res. 1996, 78, 790-798. [CrossRef]

460. Sheehy, N.T.; Cordes, K.R.; White, M.P.; Ivey, K.N.; Srivastava, D. The neural crest-enriched microRNA miR-452 regulates epithelial-mesenchymal signaling in the first pharyngeal arch. Development 2010, 137, 4307-4316. [CrossRef] [PubMed]

461. Escot, S.; Blavet, C.; Haertle, S.; Duband, J.-L.; Fournier-Thibault, C. Misregulation of SDF1-CXCR4 Signaling Impairs Early Cardiac Neural Crest Cell Migration Leading to Conotruncal Defects. Circ. Res. 2013, 113, 505-516. [CrossRef]

462. Klattenhoff, C.A.; Scheuermann, J.C.; Surface, L.E.; Bradley, R.K.; Fields, P.A.; Steinhauser, M.L.; Ding, H.; Butty, V.L.; Torrey, L.; Haas, S.; et al. Braveheart, a Long Noncoding RNA Required for Cardiovascular Lineage Commitment. Cell 2013, 152, 570-583. [CrossRef] [PubMed] 
463. Grote, P.; Wittler, L.; Hendrix, D.; Koch, F.; Währisch, S.; Beisaw, A.; Macura, K.; Bläss, G.; Kellis, M.; Werber, M.; et al. The TissueSpecific lncRNA Fendrr Is an Essential Regulator of Heart and Body Wall Development in the Mouse. Dev. Cell 2013, 24, 206-214. [CrossRef]

464. Ritter, N.; Ali, T.; Kopitchinski, N.; Schuster, P.; Beisaw, A.; Hendrix, D.A.; Schulz, M.H.; Müller-McNicoll, M.; Dimmeler, S.; Grote, P. The lncRNA Locus Handsdown Regulates Cardiac Gene Programs and Is Essential for Early Mouse Development. Dev. Cell 2019, 50, 644-657.e8. [CrossRef] [PubMed]

465. Han, X.; Zhang, J.; Liu, Y.; Fan, X.; Ai, S.; Luo, Y.; Li, X.; Jin, H.; Luo, S.; Zheng, H.; et al. The lncRNA Hand2os1 Uph locus orchestrates heart development through regulation of precise expression of Hand2. Development 2019, 146, dev176198. [CrossRef]

466. Smart, N.; Bollini, S.; Dubé, K.N.; Vieira, J.M.; Zhou, B.; Davidson, S.; Yellon, D.; Riegler, J.; Price, A.N.; Lythgoe, M.F.; et al. De novo cardiomyocytes from within the activated adult heart after injury. Nat. Cell Biol. 2011, 474, 640-644. [CrossRef] 